Supporting Information for:

\title{
Application of Aryl Siloxane Cross-Coupling to the Synthesis of Allocolchicinoids
}

\author{
W. Michael Seganish and Philip DeShong* \\ Department of Chemistry and Biochemistry, University of Maryland, College Park, Maryland 20742 \\ deshong@umd.edu
}

\section{TABLE OF CONTENTS}

General Experimental $\quad$ S2

Cross-Coupling reactions $\quad$ S2

Carbene-Ring Expansion Reactions $\quad$ S3-S11

References $\quad$ S11

NMR Spectra $\quad$ S12-45 


\section{GENERAL EXPERIMENTAL}

Thin-layer chromatography (TLC) was performed on $0.25 \mathrm{~mm}$ Merck silica gel coated plates treated with a UVactive binder with compounds being identified by UV $(254 \mathrm{~nm})$. Flash chromatography was performed using thick walled columns and medium pressure silica gel (Whatman 200-425 mesh), with column length and diameter being determined by the method of Still. ${ }^{1}$

Melting points were taken in Kimax soft glass capillary tubes using a Thomas-Hoover Uni-Melt capillary melting point apparatus (Model 6406K) equipped with a calibrated thermometer. Infrared spectra band positions are reported in reciprocal centimeters $\left(\mathrm{cm}^{-1}\right)$ and relative intensities are listed as br (broad), s (strong), $\mathrm{m}$ (medium), or w (weak).

Nuclear magnetic resonance $\left({ }^{1} \mathrm{H},{ }^{13} \mathrm{C}\right.$ NMR) spectra were recorded on a $400 \mathrm{MHz}$ spectrometer at $400 \mathrm{and} 200 \mathrm{~Hz}$ respectively. Chemical shifts are reported in parts per million $(\delta)$ relative to tetramethylsilane (TMS). Coupling constants ( $J$ values) are reported in hertz (Hz), and spin multiplicities are indicated by the following symbols: $s$ (singlet), $d$ (doublet), $t$ (triplet), q (quartet), m (multiplet), br s (broad singlet).

Low resolution mass spectrometry (LRMS) and high resolution mass spectrometry (HRMS) data are reported in the form of $\mathrm{m} / \mathrm{z}$ (intensity relative to base peak $=100$ ). The matrix used for fast atom bombardment $(\mathrm{FAB})$ was ethylene glycol.

All compounds were determined to be $>95 \%$ pure by ${ }^{1} \mathrm{H}$ NMR or GC analysis, unless otherwise noted. Previously reported compounds were characterized via ${ }^{1} \mathrm{H}$ and ${ }^{13} \mathrm{C}$ NMR and IR and compared to literature values. All new compounds were characterized using ${ }^{1} \mathrm{H}$ NMR, ${ }^{13} \mathrm{C}$ NMR, IR, low resolution and high resolution mass spectrometry.

\section{CROSS COUPLING REACTIONS}

2-Bromo-3,4,5-trimethoxy-benzaldehyde (6). Title compound was prepared according to the procedure of Fukuyama. ${ }^{2}$ The ${ }^{1} \mathrm{H}$, and ${ }^{13} \mathrm{C}$ NMR, and IR match that reported by Fukuyama. ${ }^{2}$

6-Carbaldehyde-2,3,4-trimethoxy-biphenyl (16). To a $250 \mathrm{~mL}$ round bottom flask was added 2-bromo-3,4,5trimethoxybenzaldehyde (5.00 g, $18.2 \mathrm{mmol}), \mathrm{Pd}(\mathrm{OAc})_{2}(204 \mathrm{mg}, 0.910 \mathrm{mmol})$, and $\mathrm{PPh}_{3}(1.19 \mathrm{~g}, 4.55 \mathrm{mmol})$. The flask was placed under argon and $100 \mathrm{~mL}$ of THF was added via syringe. Phenyltrimethoxysilane ( $6.75 \mathrm{~mL}, 36.4 \mathrm{mmol})$ was added to the yellow solution, followed by $36.4 \mathrm{~mL}$ of a 1.0 M solution of TBAF in THF (36.4 mmol). The reaction was heated to reflux for $18 \mathrm{~h}$, at which time, the reaction was cooled to room temperature, poured through a short pad of silica gel, and diluted with ether $(100 \mathrm{~mL})$. The organic layer was washed with water (100 mL x2), dried $\left(\mathrm{MgSO}_{4}\right)$, and evaporated to yield a yellow oil. Column chromatography (TLC $\mathrm{R}_{\mathrm{f}}=0.24$, 9:1 hexanes/EtOAc) yielded $4.66 \mathrm{~g}$ of a white solid (94\%) mp 91.2-92.4 ํ․ IR (CCl 43085 (w) 3067 (w), 3009 (w), 2960 (m), 2933 (m), 2857 (m), 1683 (s), 1587 (m), 1328 (s), 1193 (m), 1141 (s), 1096 (s); ${ }^{1} \mathrm{H}$ NMR (CDCl $) \delta 3.59$ (s, 3H), 3.94 (s, 3H), 3.99 (s, 3H), 7.30-7.35 (m, 3H), 7.42-7.43 (m, 2H), 9.63 (s, $1 \mathrm{H}) ;{ }^{13} \mathrm{C}$ NMR $\left(\mathrm{CDCl}_{3}\right) \delta 56.6,61.4,61.5,105.6,110.2,127.5,128.1,123.3,128.4,129.9,130.1,131.4,133.2$, 191.8; LRMS $\left(\mathrm{FAB}^{+}\right) \mathrm{m} / \mathrm{z} 273$ (M+ + H, 100), 272 (80), 255 (42), 230 (24), 214 (19), 151 (18), 135 (24), 119 (25), 85 (29), 55 (34), 43 (25); HRMS $\left(\mathrm{FAB}^{+}, \mathrm{M}^{+}\right.$) m/z calcd for $\mathrm{C}_{16} \mathrm{H}_{16} \mathrm{O}_{4} 272.1049$, found 272.1045 .

6-Carbaldehyde-2,3,4,4'-tetramethoxy-biphenyl (25). Title compound was prepared according to the cross-coupling procedure for biaryl 16. Column chromatography (TLC $R_{f}=0.25$, 4:1 hexanes/EtOAc) yielded a pale yellow oil. 
Recrystallization (hexane/EtOAc) provided $5.12 \mathrm{~g}$ of a white solid (93\%) mp 68.0-69.0 ${ }^{\circ} \mathrm{C}$. IR $\left(\mathrm{CCl}_{4}\right) 3002$ (m), 2954 (s), 2933 (s), 2874 (s), 2853 (m), 2836 (m), 1745 (s), 1690 (s), 1587 (s), 1480 (s), 1462 (s), 1331 (s), 1252 (s), 1152 (s), 1100 (s); ${ }^{1} \mathrm{H}$ NMR $\left(\mathrm{CDCl}_{3}\right) \delta 3.60$ (s, 3H), 3.87 (s, 3H), 3.96 (s, 3H), 4.00 (s, 3H), 6.98 (d, J=8.8, 2H), 7.25 (d, J=8.8, 2H), 7.35 (s, 1H), 9.68 (s, $1 \mathrm{H}) ;{ }^{13} \mathrm{C}$ NMR $\left(\mathrm{CDCl}_{3}\right) \delta 55.3,56.1,61.0,61.1,105.2,113.5,124.8,129.9,132.2,134.3,147.7,151.3,152.9,159.4$, 191.5; LRMS (FAB $\left.{ }^{+}\right) \mathrm{m} / \mathrm{z} 303\left(\mathrm{M}^{+}+\mathrm{H}, 100\right), 302$ (65), 285 (20); HRMS (FAB ${ }^{+}, \mathrm{M}^{+}$) m/z calcd for $\mathrm{C}_{17} \mathrm{H}_{18} \mathrm{O}_{5} 302.1154$, found 302.1154 .

6-Carbaldehyde-4'-methyl-2,3,4-trimethoxy-biphenyl (Table 1, entry 3). Title compound was prepared according to the cross-coupling procedure for biaryl 16. Column chromatography (TLC $\mathrm{R}_{\mathrm{f}}=0.23$, 9:1 hexanes/EtOAc) yielded $4.53 \mathrm{~g}$ of a white solid (87\%) mp 58.0-59.0 ํ․ IR (CCl $) 3087$ (w), 3054 (w), 3007 (m), 2967 (m), 2937 (s), 2856 (m), 1689 (s), 1586 (s), 1482 (s), 1331 (s), 1137 (s), 1097 (s), 1004 (s); ${ }^{1} \mathrm{H}$ NMR (CDCl 3 ) $\delta 2.43$ (s, 3H), 3.61 (s, 3H), 3.96 (s, 3H), 4.00 (s, 3H), 7.21 (d, J=8.0, 2H), 7.25 (d, $J=8.0,2 \mathrm{H}), 7.36$ (s, 1H), 9.66 (s, 1H); ${ }^{13} \mathrm{C}$ NMR $\left(\mathrm{CDCl}_{3}\right) \delta$ 21.3, 56.0, 56.1, 61.1, 105.1, 128.7, 129.7, 129.8, 130.9, 134.6, 137.7, 147.6, 151.2, 153.0, 191.5; LRMS (EI $\left.{ }^{+}\right)$m/z 286 (M+1 100), 271 (20), 129 (20); HRMS $\left(\mathrm{FAB}^{+}, \mathrm{M}^{+}\right) \mathrm{m} / \mathrm{z}$ calcd for $\mathrm{C}_{17} \mathrm{H}_{18} \mathrm{O}_{4} 286.1205$, found 286.1205 .

6-Carbaldehyde-4'-carboethoxy-2,3,4-trimethoxy-biphenyl (Table 1, entry 4). Title compound was prepared according to the cross-coupling procedure for biaryl 16. Column chromatography (TLC $\mathrm{R}_{\mathrm{f}}=0.28$, 4:1 hexanes/EtOAc) yielded $5.89 \mathrm{~g}$ of a colorless oil (94\%). IR (CCl 43004 (w), 2979 (m), 2939 (m), 2841 (m), 1711 (s), 1679 (s), 1588 (s), 1319 (s), 1268 (s), 1145 (s), 1086 (s), 1000 (s); ${ }^{1} \mathrm{H}$ NMR $\left(\mathrm{CDCl}_{3}\right) \delta 1.41$ (t, $\left.J=7.2,3 \mathrm{H}\right), 3.58$ (s, 3H), 3.95 (s, 3H), 3.99 (s, 3H). 4.40 (q, $J=7.2$, 2H), 7.24 (s, $1 \mathrm{H}$ ), 7.40 (d, J=8.0, 2H), 8.11 (d, $J=8.0,2 \mathrm{H}), 9.61$ (s, 3H); ${ }^{13} \mathrm{C} \mathrm{NMR}\left(\mathrm{CDCl}_{3}\right) \delta 14.4,29.0,56.2,61.1,61.2$, 105.5, 129.2, 129.5, 130.1, 131.1, 133.3, 137.8, 147.7, 151.0, 153.5, 166.3, 190.6; LRMS (FAB $\left.{ }^{+}\right) \mathrm{m} / \mathrm{z} 345\left(\mathrm{M}^{+}+\mathrm{H}, 100\right), 327$ (55), 299 (30), 55 (30); HRMS (FAB ${ }^{+}, \mathrm{M}^{+}$) m/z calcd for $\mathrm{C}_{19} \mathrm{H}_{20} \mathrm{O}_{6} 344.1260$, found 344.1275.

\section{CARBENE-RING EXPANSION REACTIONS}

\section{Model System}

9-(Methoxymethoxy)-phenanthrene (9). 9-Phenanthrol (1.00 g, $3.09 \mathrm{mmol})$ was dissolved in $25 \mathrm{~mL}$ of $\mathrm{CH}_{2} \mathrm{Cl}_{2}$. Chloromethylmethyl ether $(1.26 \mathrm{~mL}, 10.3 \mathrm{mmol})$ was added via syringe, followed by $1.12 \mathrm{~mL}$ (10.3 mmol) of Hunig's base. The brown solution was stirred at room temperature for $12 \mathrm{~h}$ to consume all of the starting material. After $12 \mathrm{~h}$, the reaction was diluted with $25 \mathrm{~mL}$ of $\mathrm{CH}_{2} \mathrm{Cl}_{2}$. The organic phase was washed with water (50 mL), $1 \mathrm{M} \mathrm{HCl}(50 \mathrm{~mL})$ and brine $(50 \mathrm{~mL})$, dried $\left(\mathrm{MgSO}_{4}\right)$, and evaporated to yield a brown oil. Column chromatography (TLC $\mathrm{R}_{\mathrm{f}}=0.41$, 9:1 hexanes/EtOAc) yielded 0.894 g of a white solid (89\%) mp 55.0-56.0 ํ․ IR (CCl $) 3077$ (m), 3060 (s), 3010 (m), 2960 (s), 2983 (s), 2850 (w), 2823 (m), 1632 (s), 1606 (s), 1452 (s), 1315 (s), 1147 (s); ${ }^{1} \mathrm{H}$ NMR (CDCl $\left.{ }_{3}\right) \delta 3.58$ (s, 3H), 5.48 (s, 2H), 7.49-7.79 (m, 6H), 8.37 (d, $J=8.0,1 \mathrm{H}), 8.58$, (d, $J=8.4,1 \mathrm{H}), 8.65$ (d, $J=8.4,1 \mathrm{H}) ;{ }^{13} \mathrm{C} \mathrm{NMR}\left(\mathrm{CDCl}_{3}\right) \delta 56.3,94.6,105.9,122.4,122.5,122.6,124.6,126.4$, 126.6, 126.9, 127.0, 127.1, 127.7, 131.3, 132.7, 150.9; LRMS (FAB ${ }^{+}$) m/z 238 (M+1 100), 207 (45), 165 (22), 45 (65); HRMS $\left(\mathrm{FAB}^{+}, \mathrm{M}^{+}\right) \mathrm{m} / \mathrm{z}$ calcd for $\mathrm{C}_{16} \mathrm{H}_{14} \mathrm{O}_{2}$ 238.0994, found 238.0999. 
7,7-Dichlorodibenzo[a,c]bicyclo(4.1.0)-6-(methoxymethoxy)-heptane (10). To a solution of 9-(methoxymethoxy)phenanthrene $(238 \mathrm{mg}, 1.00 \mathrm{mmol})$ in $10 \mathrm{~mL}$ of $\mathrm{CHCl}_{3}$ was added $22.7 \mathrm{mg}(0.100 \mathrm{mmol})$ of benzyltriethylammonium chloride and $2.00 \mathrm{~mL}$ of a $50 \%$ solution of $\mathrm{NaOH}$. The colorless biphasic mixture was stirred for $5 \mathrm{~h}$ at room temperature, during which time the reaction changed from colorless, to orange, to brown. The brown suspension was diluted with $50 \mathrm{~mL}$ of $\mathrm{CH}_{2} \mathrm{Cl}_{2}$ and poured into $50 \mathrm{~mL}$ of water. The layers were separated and the aqueous phase extracted with $\mathrm{CH}_{2} \mathrm{Cl}_{2}(3 \times 50$ $\mathrm{mL})$. The organic extracts were combined, washed with brine $(50 \mathrm{~mL})$, dried $\left(\mathrm{MgSO}_{4}\right)$, and evaporated to yield a brown oil. Column chromatography (TLC $\mathrm{R}_{\mathrm{f}}=0.32$, 9:1 hexanes/EtOAc) yielded $296 \mathrm{mg}$ of an off white solid (92\%) mp 91-92 ${ }^{\circ} \mathrm{C}$. IR (CCl $) 3077$ (w), 3037 (w), 2997 (w), 2963 (m), 2927 (m), 2896 (m), 2843 (m), 2826 (w), 1492 (m), 1455 (m), 1157 (s), 1030 (s); ${ }^{1} \mathrm{H}$ NMR $\left(\mathrm{CDCl}_{3}\right) \delta 3.44$ (s, 3H), 3.64 (s, 1H), 4.79 (dd, J=6.8, 3.8, 2H), 7.35-7.49 (m, 4H), 7.86-7.88 (m, 1H), 8.04-8.07 (m, 3H); ${ }^{13} \mathrm{C} \mathrm{NMR}\left(\mathrm{CDCl}_{3}\right) \delta$ 41.6, 56.7, 62.3, 66.4, 96.3, 122.6, 122.9, 123.1, 127.4, 128.1, 128.2, 128.3, 128.8, 128.9, 130.4, 130.9, 132.5; LRMS (FAB ${ }^{+}$) m/z 320 (M+1 10), 285 (15), 259 (100), 241 (35), 194 (40), 154 (38), 45 (90); HRMS (FAB $\mathrm{M}^{+}$) $\mathrm{m} / \mathrm{z}$ calcd for $\mathrm{C}_{17} \mathrm{H}_{14} \mathrm{O}_{2} \mathrm{Cl}_{2} 320.0371$, found 320.0367 .

6-Chloro-5H-dibenzo[a,c]cyclohepten-5-one (11). 7,7-Dichlorodibenzo[a,c]bicyclo(4.1.0)-6-(methoxymethoxy)-heptane (813 mg, $2.53 \mathrm{mmol}$ ) in $30 \mathrm{~mL}$ of IPA, $30 \mathrm{~mL}$ of THF and $30 \mathrm{~mL}$ of $2.0 \mathrm{M} \mathrm{HCl}$ was heated to $100{ }^{\circ} \mathrm{C}$ for $5 \mathrm{~h}$. The solution was cooled to room temperature and the organic solvents were removed in vacuo. The remaining mixture was partitioned between $75 \mathrm{~mL}$ of ether and water. The aqueous phase was extracted three times with ether $(50 \mathrm{~mL})$ and the combined organic extracts were dried $\left(\mathrm{MgSO}_{4}\right)$, and evaporated to yield a yellow oil. Column chromatography $\left(\mathrm{TLC} \mathrm{R}_{\mathrm{f}}=0.41,4: 1\right.$ hexanes/EtOAc) yielded $579 \mathrm{mg}$ of a white solid (95\%) mp 100.0-100.8 ${ }^{\circ} \mathrm{C}$ (lit. 98.0-98.8 $\left.{ }^{\circ} \mathrm{C}\right) .{ }^{3}$ IR $\left(\mathrm{CCl}_{4}\right) 3100(\mathrm{w}), 3070$ (m), 3030 (m), 1672 (s), 1592 (m); ${ }^{1} \mathrm{H}$ NMR $\left(\mathrm{CDCl}_{3}\right) \delta$ 7.52-7.63 (m, 4H), 7.72-7.89 (m, 2H), 7.90-7.96 (m, 3H); ${ }^{13} \mathrm{C}$ NMR $\left(\mathrm{CDCl}_{3}\right) \delta 128.6,128.8,129.6,129.7,130.0,130.9,131.0,131.4,131.9,134.1$, 136.6, 137.2, 137.7, 139.1, 187.3; LRMS $\left(\mathrm{FAB}^{+}\right) \mathrm{m} / \mathrm{z} 241\left(\mathrm{M}^{+}, 100\right), 154$ (60), 136 (55); HRMS (FAB ${ }^{+}, \mathrm{M}^{+}$) m/z calcd for $\mathrm{C}_{15} \mathrm{H}_{10} \mathrm{OCl}$ 241.0420, found 241.0419.

6,7-Dihydro-5H-dibenzo[a,c]cyclohepten-5-one (12). 6-Chloro-5H-dibenzo[a,c]cyclohepten-5-one (75.0 mg, $0.312 \mathrm{mmol}$ ), sodium acetate (79.3 mg, $0.967 \mathrm{mmol}$ ), and palladium on carbon (5\%, $65.8 \mathrm{mg}, 16.8 \mu \mathrm{mol}$ ) were stirred in $10 \mathrm{~mL}$ of EtOH under 1 ATM of hydrogen for $1 \mathrm{~h}$. The reaction mixture was filtered, and poured into $50 \mathrm{~mL}$ of ether. The organic layer was washed with water $(50 \mathrm{~mL} \mathrm{x} 2)$ and brine $(50 \mathrm{~mL})$. The ethereal phase was dried $\left(\mathrm{MgSO}_{4}\right)$, and evaporated to yield a yellow oil. Column chromatography (TLC $\mathrm{R}_{\mathrm{f}}=0.21,4: 1$ hexanes/EtOAc) yielded $46.8 \mathrm{mg}$ of a white solid (72\%) $\mathrm{mp} 84.5-85.6^{\circ} \mathrm{C}$ (lit. 85-86 ㄷ). ${ }^{3}$ IR (CCl $) 3074$ (m), 3027 (m), 2957 (m), 2927 (w), 2863 (w), 1689 (s), 1596 (m), 1448 (m), 1271 (s); ${ }^{1} \mathrm{H}$ $\operatorname{NMR}\left(\mathrm{CDCl}_{3}\right) \delta 2.99(\mathrm{~s}, 4 \mathrm{H}), 7.27-7.46(\mathrm{~m}, 6 \mathrm{H}), 7.58-7.67(\mathrm{~m}, 2 \mathrm{H}) ;{ }^{1} \mathrm{H}$ NMR (benzene $\left.\mathrm{d}_{6}\right) \delta 2.45(\mathrm{t}, J=6.8,2 \mathrm{H}), 2.63(\mathrm{t}$, $J=6.8,2 \mathrm{H}), 6.85-6.87$ (m, 1H), 7.05-7.16 (m, 6H), 7.80-7.82 (m, 1H); ${ }^{13} \mathrm{C} \mathrm{NMR}\left(\mathrm{CDCl}_{3}\right) \delta 29.5,47.6,127.6,127.9,128.0$, 128.4, 128.6, 129.6, 130.0, 132.2, 138.8, 138.9, 139.0, 139.5, 206.2; LRMS (EI $\left.{ }^{+}\right) \mathrm{m} / \mathrm{z} 208\left(\mathrm{M}^{+}, 100\right), 180$ (90), 179 (70), 165 (39), 152 (25); HRMS (EI ${ }^{+}, \mathrm{M}^{+}$) m/z calcd for $\mathrm{C}_{15} \mathrm{H}_{12} \mathrm{O}$ 208.0888, found 208.0895.

6,7-Dihydro-5H-dibenzo[a,c]cyclohepten-5-ol (13). 6-Chloro-5H-dibenzo[a,c]cyclohepten-5-one (75.0 mg, $0.312 \mathrm{mmol}$ ), sodium acetate (79.3 mg, $0.967 \mathrm{mmol}$ ), and palladium on carbon (5\%, $65.8 \mathrm{mg}, 0.0168 \mathrm{mmol}$ ) were stirred in $10 \mathrm{~mL}$ of EtOH under 1 ATM of hydrogen for $24 \mathrm{~h}$. The reaction mixture was filtered, and poured into $50 \mathrm{~mL}$ of ether. The organic layer 
was washed with water $\left(50 \mathrm{~mL}\right.$ x2) and brine $(50 \mathrm{~mL})$. The ethereal phase was dried $\left(\mathrm{MgSO}_{4}\right)$, and evaporated to yield a yellow oil. Column chromatography (TLC $\mathrm{R}_{\mathrm{f}}=0.25$, 4:1 hexanes/EtOAc) yielded $43.0 \mathrm{mg}$ of a white solid (66\%) mp 114.5$115.0{ }^{\circ} \mathrm{C}$. IR (CCl 3619 (s), 3070 (m), 3020 (m), 2940 (s), 2860 (m), 1482 (m), 1455 (m), 1047 (s); ${ }^{1} \mathrm{H} \mathrm{NMR}\left(\mathrm{CDCl}_{3}\right) \delta$ 2.08-2.10 (m, 1H), 2.46-2.67 (m, 4H), 4.65-4.67 (m, 1H), 7.25-7.64 (m, 7H), 7.64-7.65 (m, 1H); ${ }^{13} \mathrm{C} \mathrm{NMR}\left(\mathrm{CDCl}_{3}\right) \delta 30.1$, 41.9, 70.6, 123.1, 123.2, 126.9, 127.3, 127.6, 127.8, 128.2, 128.3, 137.9, 139.4, 139.8, 141.5; LRMS (EI $\left.{ }^{+}\right) \mathrm{m} / \mathrm{z} 210\left(\mathrm{M}^{+}, 100\right)$, 192 (90), 191 (40), 165 (30), 152 (20); HRMS $\left(\mathrm{EI}^{+}, \mathrm{M}^{+}\right.$) m/z calcd for $\mathrm{C}_{15} \mathrm{H}_{14} \mathrm{O}$ 210.1045, found 210.1035.

5H-dibenzo[a,c]cyclohepten-5-one (14). Title compound was prepared according to a procedure by Jones and coworkers ${ }^{3}$ starting with $150 \mathrm{mg}(0.623 \mathrm{mmg})$ of 6-chloro-5H-dibenzo[a,c]cyclohepten-5-one and yielding $102 \mathrm{mg}$ of the title compound as a white solid (79\%) mp 82.3-83.7 ${ }^{\circ} \mathrm{C}$ (lit. 83-84.5 $\left.{ }^{\circ} \mathrm{C}\right){ }^{3}$ IR (CCl $) 3060$ (w), 3031 (m), 2953 (s), 2921 (m), 2847 (w), 1658 (s); ${ }^{1} \mathrm{H}$ NMR $\left(\mathrm{CDCl}_{3}\right) \delta 6.66$ (d, J=12.0, 1H), 7.35 (d, J=12.0, 1H), 7.47-7.59 (m, 4H), 7.65-7.69 (m, 1H), 7.88-7.96 (m, 3H); ${ }^{13} \mathrm{C} \mathrm{NMR}\left(\mathrm{CDCl}_{3}\right) \delta 110.8,128.2,128.5,129.0,129.4,130.3,131.1,131.5,131.6,133.1,137.0,138.2,139.9,141.2,192.6$; LRMS (EI $\left.{ }^{+}\right)$m/z $206\left(\mathrm{M}^{+}, 40\right), 178$ (100), 176 (30), 88 (30); HRMS (EI ${ }^{+}, \mathrm{M}^{+}$) m/z calcd for $\mathrm{C}_{15} \mathrm{H}_{10} \mathrm{O}$ 206.732, found 206.0728.

6-Phenyl-5H-dibenzo[a,c]cyclohepten-5-one (15). 6-Chloro-5H-dibenzo[a,c]cyclohepten-5-one (240 mg, 1.00 mmol) was weighed into a $25 \mathrm{~mL}$ round bottom flask and placed under argon. Tetrakis(triphenylphosphine)palladium(0) (116 mg, 0.100 mmol) was added, followed by $10 \mathrm{~mL}$ of benzene, and $1.50 \mathrm{~mL}$ (3.00 mmol) of a $2 \mathrm{M}$ aqueous solution of $\mathrm{Na}_{2} \mathrm{CO}_{3}$. Phenyl boronic acid ( $377 \mathrm{mg}, 3.00 \mathrm{mmol}$ ) in $3 \mathrm{~mL}$ of EtOH was added via syringe. The reaction mixture was brought to reflux for $72 \mathrm{~h}$ to consume all of the $\alpha$-chloro enone. The reaction was cooled to room temperature and diluted with water (30 mL), and ether $(30 \mathrm{~mL})$. The layers were separated and the aqueous phase extracted twice with $30 \mathrm{~mL}$ of ether. The organic phases were combined and dried $\left(\mathrm{MgSO}_{4}\right)$ and evaporated to yield a yellow solid. Column chromatography $\left(\mathrm{TLC} \mathrm{R}_{\mathrm{f}}=0.31\right.$, 9:1 hexanes/EtOAc) yielded $200 \mathrm{mg}$ of a white solid (71\%) mp 136.8-138.2 ${ }^{\circ} \mathrm{C}$. IR (CCl $\left.{ }_{4}\right) 3030$ (m), 3023 (w), 2921 (s), 2843 (m), 1670 (s), 1368 (m), 1290 (s); ${ }^{1} \mathrm{H}$ NMR $\left(\mathrm{CDCl}_{3}\right) \delta$ 7.36-7.68 (m, 10H), 7.77-7.90 (m, 1H), 7.85-7.89 (m, 2H); ${ }^{13} \mathrm{C}$ NMR $\left(\mathrm{CDCl}_{3}\right) \delta 127.6,127.9,128.1,128.4,128.5,128.7,129.2,130.4,131.0,133.3,135.2,136.2,137.1,138.4,143.4,144.4$, 196.2; LRMS (EI $)$ m/z $282\left(\mathrm{M}^{+}\right.$, 30), 254 (100), 252 (60); HRMS ( $\mathrm{EI}^{+}, \mathrm{M}^{+}$) m/z calcd for $\mathrm{C}_{21} \mathrm{H}_{14} \mathrm{O}$ 282.1045, found 282.1036 .

\section{Phenyl System}

2,3,4-Trimethoxy-6-((E/Z)-2-methoxyvinyl)biphenyl. Sodium hydride (60\% dispersion in mineral oil, 2.15 g, 53.6 mmol) was added to a $250 \mathrm{~mL}$ round bottom flask and placed under argon. The sodium hydride was washed three times with dry pentane to remove the mineral oil. Ether was added $(130 \mathrm{~mL})$, followed by methoxymethyltriphenylphosphonium chloride (20.2 g, $57.6 \mathrm{mmol}$ ), which was added in three portions over $10 \mathrm{~min}$. The reaction mixture was brought to reflux for $30 \mathrm{~min}$ and cooled to room temperature. 2,3,4-Trimethoxy-6-carbaldehyde-biphenyl (3.64 g, 13.4 mmol) was added in one portion. The reaction was heated to reflux for $12 \mathrm{~h}$ to consume all of the aldehyde, after which time the reaction was filtered, and diluted with $100 \mathrm{~mL}$ of ether. The organic layer was washed with water (100 mL x2), 1 M HCl (100 mL), brine (100 mL), 
dried $\left(\mathrm{MgSO}_{4}\right)$, and evaporated to yield a white solid. Column chromatography (TLC $\mathrm{R}_{\mathrm{f}}=0.34,4: 1$ hexanes/EtOAc) yielded $3.90 \mathrm{~g}$ of a white solid (97\%) mp 105-108 ${ }^{\circ} \mathrm{C}$ as a 60:40 mixture of E/Z isomers which were not separated. IR $\left(\mathrm{CCl}_{4}\right) 3060$ (m), 3003 (m), 2957 (s), 2930 (s), 2903 (m), 2830 (m), 1639 (s), 1489 (s), 1398 (s), 1328 (s), 1147 (s), 1101 (s); LRMS

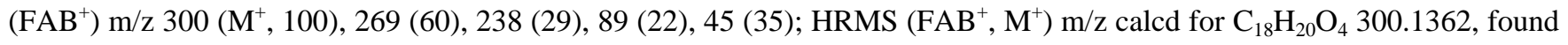
300.1367.

6-Acetylaldehyde-2,3,4-trimethoxybiphenyl. 2,3,4-Trimethoxy-6-((E/Z)-2-methoxyvinyl)biphenyl (5.25 g, 17.5 mmol) was dissolved in $50 \mathrm{~mL}$ of THF. A $2.0 \mathrm{M} \mathrm{HCl}(0.600 \mathrm{~mL}, 13.1 \mathrm{mmol})$ solution was added and the reaction was refluxed for $1.5 \mathrm{~h}$. The pale yellow solution was diluted with $75 \mathrm{~mL}$ of ethyl acetate, washed twice with $50 \mathrm{~mL}$ of a sat. solution of $\mathrm{NaHCO}_{3}$, water $(50 \mathrm{~mL})$, brine $(50 \mathrm{~mL})$, dried $\left(\mathrm{MgSO}_{4}\right)$, and evaporated to yield a yellow solid. Column chromatography (TLC $\mathrm{R}_{\mathrm{f}}=0.28$, 4:1 hexanes/EtOAc) yielded a viscous oil which crystallized upon cooling to provide $3.58 \mathrm{~g}$ of the title compound as white needles (97\%) mp 56.0-56.5 ${ }^{\circ} \mathrm{C}$. IR ( $\left.\mathrm{CCl}_{4}\right) 3064$ (w), 2993 (m), 2963 (m), 2940 (s), 2833 (m), 2719 (w), 1733 (s), 1489 (s), 1147 (s), 1101 (s); ${ }^{1} \mathrm{H}$ NMR $\left(\mathrm{CDCl}_{3}\right) \delta 3.47$ (s, 2H), 3.61 (s, 3H), 3.89 (s, 3H), 3.92 (s, 3H), 6.55 (s, 1H), 7.17-7.19 (m, 2H), 7.34-7.43 (m, 3H), 9.55 (s, 1H); ${ }^{13} \mathrm{C}$ NMR $\left(\mathrm{CDCl}_{3}\right) \delta$ 48.4, 56.1, 60.9, 61.0, 109.2, 126.1, 127.4, 128.3, 130.0, 130.2, 136.5, 141.6, 151.9, 152.9, 199.4; LRMS (FAB ${ }^{+}$) m/z $286\left(\mathrm{M}^{+}, 40\right), 269$ (100), 258 (60), 242 (43), 226 (40); HRMS (FAB ${ }^{+}, \mathrm{M}^{+}$) m/z calcd for $\mathrm{C}_{17} \mathrm{H}_{18} \mathrm{O}_{4}$ 286.1205, found 286.1217 .

6-(Acetic acid)-2,3,4-trimethoxybiphenyl (17). A stock solution of Jones reagent was prepared by dissolving $5.0 \mathrm{~g}$ of $\mathrm{CrO}_{3}$ in $7 \mathrm{~mL}$ of water. The red solution was cooled to $0{ }^{\circ} \mathrm{C}$ and sulfuric acid $(4.21 \mathrm{~mL})$ was added dropwise, followed by an additional $18 \mathrm{~mL}$ of water. 6-Acetylaldehyde-2,3,4-trimethoxybiphenyl (3.76 g, $13.1 \mathrm{mmol}$ ) was dissolved in $130 \mathrm{~mL}$ of acetone and the colorless solution was cooled to $0{ }^{\circ} \mathrm{C}$. Jones reagent was added dropwise until the persistence of a deep red color. Isopropanol was added dropwise to quench the excess Jones reagent, forming a dark green reaction mixture. The solvents were removed in vacuo and the residue was dissolved in $100 \mathrm{~mL}$ of $1 \mathrm{M} \mathrm{NaOH}$. The aqueous layer was washed with ether $\left(50 \mathrm{~mL}\right.$ x2) and acidified with concentrated $\mathrm{HCl}$. The aqueous suspension was extracted with $\mathrm{CH}_{2} \mathrm{Cl}_{2}(75 \mathrm{~mL} \mathrm{x} 3)$. The combined organic extracts were dried $\left(\mathrm{MgSO}_{4}\right)$, and evaporated to yield $3.76 \mathrm{~g}$ of a white solid (95\%) mp 108.0-108.5 ${ }^{\circ} \mathrm{C}$. IR (CCl 3528 (m), 3060 (m), 3007 (m), 2960 (m), 2933 (m), 2840 (m), 1709 (s), 1489 (m), 1395 (m), 1147 (s), 1104 (s); ${ }^{1} \mathrm{H}$ NMR $\left(\mathrm{CDCl}_{3}\right) \delta 3.43$ (s, 2H), 3.60 (s, 3H), 3.90 (s, 3H), 3.91 (s, 3H), 6.68 (s, 1H), 7.22-7.24 (m, 2H), 7.35-7.42 (m, 3H), 9.20 (br, 1H); ${ }^{13} \mathrm{C}$ NMR $\left(\mathrm{CDCl}_{3}\right) \delta$ 38.1, 56.0, 60.9, 61.0, 108.9, 127.2, 127.8, 128.2, 129.9, 130.1, 136.4, 136.7, 151.6, 152.7, 175.0; LRMS (FAB ${ }^{+}$) m/z $302\left(\mathrm{M}^{+}, 100\right), 257$ (25), 226 (20); HRMS (FAB ${ }^{+}, \mathrm{M}^{+}$) m/z calcd for $\mathrm{C}_{17} \mathrm{H}_{18} \mathrm{O}_{5} 302.1154$, found 302.1144 .

2,3,4-Trimethoxy-9-phenanthrol (18). 6-(Acetic acid)-2,3,4-trimethoxybiphenyl (3.76 g, 12.4 mmol) was dissolved in $36.0 \mathrm{~mL} \mathrm{SOCl} 2$ and brought to a gentle reflux for $2 \mathrm{~h}$. Excess thionyl chloride was removed in vacuo. The residue was dissolved in $50 \mathrm{~mL}$ of benzene and added dropwise to a stirred, cooled $\left(5{ }^{\circ} \mathrm{C}\right)$ mixture of $\mathrm{AlCl}_{3}(3.31 \mathrm{~g}, 24.8 \mathrm{mmol})$ in benzene $(80 \mathrm{~mL})$. The reaction mixture was allowed to warm to room temperature, at which time $100 \mathrm{~mL}$ of a $1.0 \mathrm{M} \mathrm{HCl}$ solution was added in one portion. The phases were separated and the aqueous layer extracted with EtOAc (75 mL x3). The combined organic extracts were dried $\left(\mathrm{MgSO}_{4}\right)$, and evaporated to yield a brown oil. Column chromatography $\left(\mathrm{TLC} \mathrm{R}_{\mathrm{f}}=\right.$ 
0.31, 1:1 hexanes/EtOAc) yielded $2.19 \mathrm{~g}$ of an air sensitive off-white solid which was immediately stored under argon (62\%) mp 130-132 ㄷ (decomp). IR ( $\left.\mathrm{CCl}_{4}\right) 3609$ (m), 3064 (w), 2997 (m), 2960 (m), 2933 (s), 2876 (m), 2856 (m), 1746 (m), 1609 (m), 1469 (s), 1221 (s), 1101 (s); ${ }^{1} \mathrm{H}_{\mathrm{NMR}}\left(\mathrm{CDCl}_{3}\right) \delta 3.99$ (s, 3H), 4.01 (s, 3H), 4.02 (s, 3H), 5.22 (s, 1H), 6.91 (s, 1H), 6.92 (s, 1H), 7.59-7.66 (m, 2H), 8.29 (d, $J=8.0,1 \mathrm{H}), 9.52$ (d, $J=8.0,1 \mathrm{H}) ;{ }^{13} \mathrm{C} \mathrm{NMR}\left(\mathrm{CDCl}_{3}\right) \delta 56.4,60.9,61.9,104.1,106.8,115.7$, 122.3, 125.5, 125.9, 127.3, 128.0, 131.2, 131.9, 141.6, 149.9, 153.2, 153.4; LRMS (FAB ${ }^{+}$) m/z $284\left(\mathrm{M}^{+}, 100\right), 154$ (30), 136 (40); HRMS $\left(\mathrm{FAB}^{+}, \mathrm{M}^{+}\right.$) m/z calcd for $\mathrm{C}_{16} \mathrm{H}_{16} \mathrm{O}_{4} 284.1049$, found 284.1050.

2,3,4-Trimethoxy-9-(methoxymethoxy)-phenanthrene (19). 3,4,5-Trimethoxy-9-phenanthrol (2.19 g, 7.71 mmol) was dissolved in $40 \mathrm{~mL}$ of $\mathrm{CH}_{2} \mathrm{Cl}_{2}$. To this dark brown solution was added $1.88 \mathrm{~mL}$ (15.4 mmol) of chloromethylmethyl ether, followed by $1.67 \mathrm{~mL}$ of Hunig's base $(15.4 \mathrm{mmol})$. The light brown solution was stirred at room temperature for $12 \mathrm{~h}$ to consume all of the starting material (TLC). The reaction was diluted with ether (150 mL), washed with water (100 mL), 1M $\mathrm{HCl}(100 \mathrm{~mL})$, brine $(100 \mathrm{~mL})$, dried $\left(\mathrm{MgSO}_{4}\right)$, and evaporated to yield a brown oil. Column chromatography $\left(\mathrm{TLC} \mathrm{R}_{\mathrm{f}}=\right.$ 0.27, 4:1 hexanes/EtOAc) yielded $2.13 \mathrm{~g}$ of a white solid (84\%) mp 91.1-92.5 ${ }^{\circ} \mathrm{C}$. IR ( $\left.\mathrm{CCl}_{4}\right) 3074(\mathrm{w}), 3000(\mathrm{~m}), 2963(\mathrm{~m})$, 2933 (s), 2903 (m), 2826 (m), 1632 (s), 1612 (s), 1502 (s), 1462 (s), 1351 (s), 1144 (s), 1064 (s); ${ }^{1} \mathrm{H}$ NMR $\left(\mathrm{CDCl}_{3}\right) \delta 3.58$ (s, 3H), 4.00 (s, 3H), 4.01 (s, 3H), 4.02 (s, 3H), 5.47 (s, 2H), 7.02 (s, 1H), 7.20 (s, 1H), 7.55-7.67 (m, 2H), 8.36 (d, J=8.0, 1H), 9.50 (d, $J=8.0,1 \mathrm{H}) ;{ }^{13} \mathrm{C} \mathrm{NMR}\left(\mathrm{CDCl}_{3}\right) \delta 55.8,56.2,60.3,61.3,94.6,104.5,106.0,115.2,121.9,125.3,125.9,126.6,127.2$, 130.6, 131.0, 141.3, 150.7, 152.4, 152.7; LRMS (FAB ${ }^{+}$) m/z $328\left(\mathrm{M}^{+}, 100\right), 297$ (20), 283 (25); HRMS (FAB $\left.{ }^{+}, \mathrm{M}^{+}\right) \mathrm{m} / \mathrm{z}$ calcd for $\mathrm{C}_{19} \mathrm{H}_{20} \mathrm{O}_{5} 328.1311$, found 328.1318 .

\section{1,1-Dichloro-1a,9b-dihydro-6,7,8-trimethoxy-1a-(methoxymethoxy)-1H-cyclopropa[I]phenanthrene $\quad$ (20). 2,3,4-}

Trimethoxy-9-(methoxymethoxy)-phenanthrene $(2.13 \mathrm{~g}, 6.49 \mathrm{mmol})$ and $148 \mathrm{mg}(0.649 \mathrm{mmol})$ of benzyltriethylammonium chloride were dissolved in $65 \mathrm{~mL}$ of $\mathrm{CHCl}_{3}$. To this colorless solution was added $13 \mathrm{~mL}$ of $50 \% \mathrm{NaOH}$ in one portion. The biphasic reaction mixture was stirred vigorously at room temperature for $6 \mathrm{~h}$ during which time the reaction changed from pale yellow to orange to brown. The reaction mixture was diluted with $\mathrm{CH}_{2} \mathrm{Cl}_{2}(100 \mathrm{~mL})$ and water $(100 \mathrm{~mL})$. The layers were separated and the aqueous phase was extracted with $\mathrm{CH}_{2} \mathrm{Cl}_{2}(75 \mathrm{~mL}$ x3). The combined organic extracts were dried $\left(\mathrm{MgSO}_{4}\right)$, and evaporated to yield a brown oil. Column chromatography (TLC $\mathrm{R}_{\mathrm{f}}=0.26$, 4:1 hexanes/EtOAc) yielded $1.95 \mathrm{~g}$ of a yellow oil (73\%) which was used without further purification. IR ( $\left.\mathrm{CCl}_{4}\right) 3137$ (w), 3064 (w), 2997 (m), 2957 (s), 2937 (s), 2846 (m), 1596 (s), 1492 (s), 1328 (s), 1161 (s); ${ }^{1} \mathrm{H}$ NMR (CDCl $\left.{ }_{3}\right) \delta 3.45$ (s, 3H), 3.56 (s, 1H), 3.85 (s, 3H), 3.93 (s, 3H), 3.96 (s, 3H), 4.78 (q $\left.\mathrm{q}_{\mathrm{AB}}, J=6.8,7.2,2 \mathrm{H}\right), 6.80$ (s, 1H), 7.26-7.42 (m, 2H), 7.84-7.85 (m, 1H), 8.94-8.96 (m, 1H); ${ }^{13} \mathrm{C}$ NMR $\left(\mathrm{CDCl}_{3}\right) \delta 42.1,55.9,56.7,60.4,61.0,62.4,66.6,96.2,109.8,117.7,125.1,126.9,127.0,128.5,129.0,132.5,143.2,152.9$, 153.8; LRMS (FAB ${ }^{+}$) m/z 410 (M+10), 349 (100), 331 (70), 283 (90), 154 (65), 136 (50), 45 (85); HRMS (FAB , M ${ }^{+}$) m/z calcd for $\mathrm{C}_{20} \mathrm{H}_{20} \mathrm{O}_{5} \mathrm{Cl}_{2}$ 410.0688, found 410.0687 .

6-Chloro-1,2,3-trimethoxy-5H-dibenzo[a,c]cyclohepten-7-one (22). 1,1-Dichloro-1a,9b-dihydro-6,7,8-trimethoxy-1a(methoxymethoxy)-1H-cyclopropa[l]phenanthrene $(757 \mathrm{mg}, 1.84 \mathrm{mmol}$ ) was dissolved in $12 \mathrm{~mL}$ of THF, $12 \mathrm{~mL}$ of $i \operatorname{PrOH}$, and $12 \mathrm{~mL}$ of $2 \mathrm{M} \mathrm{HCl}$. The reaction mixture was heated to $100{ }^{\circ} \mathrm{C}$ for $5 \mathrm{~h}$. The solution was cooled to room temperature and the organic solvents were removed in vacuo. The remaining mixture was partitioned between $50 \mathrm{~mL}$ of ether and $50 \mathrm{~mL}$ 
of water. The aqueous phase was extracted three times with ether $(30 \mathrm{~mL})$ and the combined organic extracts were dried, $\left(\mathrm{MgSO}_{4}\right)$, and evaporated to yield a yellow oil. Column chromatography (TLC $\mathrm{R}_{\mathrm{f}}=0.26$, 4:1 hexanes/EtOAc) yielded a light yellow solid. Recrystallization (benzene/pentane) provided $407 \mathrm{mg}$ of colorless crystals (67\%) mp 141.1-141.8 ${ }^{\circ} \mathrm{C}$. IR (CCl $) 3064$ (w), 3007 (m), 2963 (s), 2927 (s), 2850 (s), 1733 (m), 1672 (s), 1592 (s), 1492 (s), 1338 (s), 1151 (s), 1121 (s); ${ }^{1} \mathrm{H}$ NMR (CDCl $) \delta 3.44$ (s, 3H), 3.96 (s, 3H), 4.00 (s, 3H), 6.75 (s, 1H), 7.50-7.59 (m, 2H), 7.57 (s, 1H), 7.78-7.80 (m, 1H), 8.02-8.04 (m, 1H); ${ }^{13} \mathrm{C}$ NMR $\left(\mathrm{CDCl}_{3}\right) \delta 56.1,61.2,61.4,108.6,124.7,127.8,128.2,128.4,130.0,131.7,132.1,133.1,137.0$, 139.6, 144.1, 152.9, 153.0, 188.3; LRMS (FAB ${ }^{+}$) m/z 331 ( $\mathrm{M}^{+}$, 30), 307 (22), 154 (35), 137 (100); HRMS (FAB ${ }^{+} \mathrm{M}^{+}$) m/z calcd for $\mathrm{C}_{18} \mathrm{H}_{16} \mathrm{O}_{4} \mathrm{Cl}$ 331.0737, found 331.0733.

5,6-Dihydro-1,2,3-trimethoxy-5H-dibenzo[a,c]cyclohepten-7-one (23). 6-Chloro-1,2,3-trimethoxy-5Hdibenzo[a,c]cyclohepten-7-one (36.5 mg, $0.110 \mathrm{mmol}$ ), sodium acetate (22.6 mg, $0.275 \mathrm{mmol}$ ), and palladium on carbon (5\%, $11.7 \mathrm{mg}, 5.52 \mu \mathrm{mol}$ ) were stirred in $5 \mathrm{~mL}$ of EtOH under 1 ATM of hydrogen for $1 \mathrm{~h}$. The reaction mixture was filtered, and poured into $25 \mathrm{~mL}$ of ether. The organic layer was washed with water $(25 \mathrm{~mL}$ x2) and brine $(25 \mathrm{~mL})$. The ethereal phase was dried $\left(\mathrm{MgSO}_{4}\right)$, and evaporated to yield a yellow oil. Column chromatography $\left(\mathrm{TLC} \mathrm{R}_{\mathrm{f}}=0.21\right.$, 4:1 hexanes/EtOAc) yielded a colorless oil, which was recrystallized from hexane to provide $26.0 \mathrm{mg}$ of white crystals (72\%) mp 79.0-80.0 ㄷ․ IR (CCl ${ }_{4}$ 3067, (w), 3000 (m), 2957 (m), 2933 (s), 2863 (m), 2836 (m), 1689 (s), 1599 (s), 1405 (s), 1348 (s), 1114 (s); ${ }^{1} \mathrm{H}$ NMR $\left(\mathrm{CDCl}_{3}\right) \delta$ 2.64-2.67 (m, 1H), 2.88-3.09 (m, 3H), 3.50 (s, 3H), 3.90 (s, 3H), 3.91 (s, 3H), 6.61 (s, 1H), 7.37-7.41 (m, 1H), 7.51-7.79 (m, 3H); ${ }^{13} \mathrm{C}$ NMR $\left(\mathrm{CDCl}_{3}\right) \delta$ 31.3, 48.4, 56.5, 61.4, 61.6, 107.4, 124.7, 127.8, 128.0, 131.2,

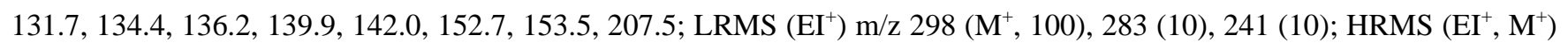
$\mathrm{m} / \mathrm{z}$ calcd for $\mathrm{C}_{18} \mathrm{H}_{18} \mathrm{O}_{4}$ 298.1205, found 298.1203 .

5-Acetamido-5,6-dihydro-1,2,3-trimethoxy-5H-dibenzo[a,c]cycloheptene (24). Title compound was prepared from 114 $\mathrm{mg}(0.380 \mathrm{mmol})$ of 5,6-dihydro-1,2,3-trimethoxy-5H-dibenzo[a,c]cyclohepten-7-one according to the reductive amination/acylation protocol of Wulff and coworkers ${ }^{4}$ to yield $73.9 \mathrm{mg}$ (57\%) of the titled compound as a white solid mp 184.3-187.1 (lit. 185.2-187.6). ${ }^{5}$ The ${ }^{1} \mathrm{H}$ and ${ }^{13} \mathrm{C}$ NMR, and IR spectral data match those reported by Fagnou and coworkers. ${ }^{5}$

\section{NCME System}

2,3,4,4'-Tetramethoxy-6-(methanol)-biphenyl. Sodium borohydride (843 mg, $22.3 \mathrm{mmol}$ ) was added in small portions at 0 ${ }^{\circ} \mathrm{C}$ to a stirred solution of 6-carbaldehyde-2,3,4,4'-tetramethoxy-biphenyl (5.39 mg, $18.6 \mathrm{mmol}$ ) in $75 \mathrm{~mL}$ of $\mathrm{MeOH}$. The reaction was stirred at room temperature overnight to consume all of the aldehyde, at which time the reaction mixture was poured into $100 \mathrm{~mL}$ of cold $1 \mathrm{M} \mathrm{HCl}$ and extracted with ether $(100 \mathrm{~mL} \mathrm{x} 3)$. The combined organic extracts were dried $\left(\mathrm{MgSO}_{4}\right)$, and evaporated to yield a yellow oil. Column chromatography (TLC $\mathrm{R}_{\mathrm{f}}=0.32$, 1:1 hexanes/EtOAc) yielded $4.81 \mathrm{~g}$ of a white solid (85\%) mp 81.0-82.0 ㄷ. IR (CCl 3613 (m), 3002 (w), 2957 (m), 2937 (m), 2902 (w), 2833 (m), 1597 (m), 1494 (s), 1245 (s); ${ }^{1} \mathrm{H}$ NMR (CDCl $) \delta 3.60$ (s, 3H), 3.86 (s, 3H), 3.91 (s, 3H), 3.93 (s, 3H), 4.42 (s, 2H), 6.90 (s, 1H), 6.96 (d, $J=8.4,2 \mathrm{H}), 7.18$ (d, $J=8.4,2 \mathrm{H}) ;{ }^{13} \mathrm{C}$ NMR $\left(\mathrm{CDCl}_{3}\right) \delta 55.2,56.0,60.9,61.0,63.2,106.9,113.6,127.8,128.0,131.0,134.7$, 
141.2, 151.3, 153.4, 158.7; LRMS (EI ${ }^{+}$) m/z 304 (M+100), 287 (80), 256 (50); HRMS (EI $\left.{ }^{+}, \mathrm{M}^{+}\right) \mathrm{m} / \mathrm{z}$ calcd for $\mathrm{C}_{17} \mathrm{H}_{20} \mathrm{O}_{5}$ 304.1311, found 304.1324.

2,3,4,4'-Tetramethoxy-6-(bromomethyl)-biphenyl. Phosphorous tribromide (1.40 mL, $14.7 \mathrm{mmol}$ ) in $30 \mathrm{~mL}$ of $\mathrm{CH}_{2} \mathrm{Cl}_{2}$ was added dropwise to a cold $\left(0^{\circ} \mathrm{C}\right)$, stirred solution of 2,3,4,4'-tetramethoxy-6-(methanol)-biphenyl (6.05 g, $\left.19.9 \mathrm{mmol}\right)$ in $90 \mathrm{~mL}$ of $\mathrm{CH}_{2} \mathrm{Cl}_{2}$. The reaction was stirred for $45 \mathrm{~min}$ at $0{ }^{\circ} \mathrm{C}$, at which time the solution was poured into ice water and extracted with $\mathrm{CH}_{2} \mathrm{Cl}_{2}(50 \mathrm{~mL}, \mathrm{x} 2)$. The combined organic extracts were dried $\left(\mathrm{MgSO}_{4}\right)$, and evaporated to yield a yellow oil. Column chromatography (TLC $\mathrm{R}_{\mathrm{f}}=0.31$, 4:1 hexanes/EtOAc) yielded $6.50 \mathrm{~g}$ of a white solid (89\%) mp 73.0-74.0 ${ }^{\circ} \mathrm{C}$. IR $\left(\mathrm{CCl}_{4}\right) 3037$ (w), 2997 (m), 2957 (s), 2940 (s), 2903 (m), 2836 (s), 1599 (s), 1489 (s), 1335 (s), 1238 (s); ${ }^{1} \mathrm{H}$ NMR (CDCl $) \delta$ 3.58 (s, 3H), 3.87 (s, 3H), 3.91 (s, 3H), 3.92 (s, 3H), 4.29 (s, 2H), 6.82 (s, 1H), 6.97 (d, J=8.4, 2H), 7.25 (d, $J=8.4,2 \mathrm{H}) ;{ }^{13} \mathrm{C}$ NMR $\left(\mathrm{CDCl}_{3}\right) \delta 32.8,55.2,56.1,60.9,109.1,113.6,127.6,129.4,131.0,131.5,142.6,151.7,152.8,158.8$; LRMS (EI $\left.{ }^{+}\right) \mathrm{m} / \mathrm{z}$ 366 ( $\left.\mathrm{M}^{+}, 70\right), 287$ (90), 256 (100), 241 (60); HRMS (EI ${ }^{+}, \mathrm{M}^{+}$) m/z calcd for $\mathrm{C}_{17} \mathrm{H}_{19} \mathrm{O}_{4} \mathrm{Br}$ 366.0467, found 366.0484.

6-Acetonitrile-2,3,4,4'-tetramethoxy-biphenyl. 6-Carbaldehyde-2,3,4,4'-tetramethoxy-biphenyl (885 mg, $2.41 \mathrm{mmol}$ ) and potassium cyanide (188 $\mathrm{mg}, 2.89 \mathrm{mmol})$ were added to a round bottom flask. DMSO $(15 \mathrm{~mL})$ and water $(2.5 \mathrm{~mL})$ were added and the reaction heated to $60{ }^{\circ} \mathrm{C}$ for $3 \mathrm{~h}$ to consume all of the starting material (TLC). After cooling to room temperature, the reaction mixture was diluted with $75 \mathrm{~mL}$ of ether, and washed with water $(75 \mathrm{~mL} \mathrm{x} 3)$ and once with brine. The ethereal phase was dried $\left(\mathrm{MgSO}_{4}\right)$, and evaporated to yield a yellow solid. Column chromatography $\left(\mathrm{TLC} \mathrm{R}_{\mathrm{f}}=0.29\right.$, 4:1 hexanes/EtOAc) yielded $673 \mathrm{mg}$ of a white solid (89\%) mp 99-100 ㄷ. IR (CCl 4$) 3000$ (s), 2971 (s), 2939 (s), 2835 (s), 2252 (m), 1595 (s), 1495 (s), 1456 (s), 1398 (m), 1333 (s), 1239 (s), 1100 (s); $\left.{ }^{1} \mathrm{H} \mathrm{NMR} \mathrm{(CDCl}_{3}\right) \delta 3.44$ (s, 2H), 3.60 (s, 3H), 3.86 (s, 3H), 3.91 (s, 3H), 3.91 (s, 3H), 6.83 (s, 1H), 6.98 (d, $J=8.0,2 \mathrm{H}), 7.14$ (d, $J=8.0,2 \mathrm{H}) ;{ }^{13} \mathrm{C}$ NMR $\left(\mathrm{CDCl}_{3}\right) \delta 22.1,55.3,56.2$, 60.9, 61.0, 107.5, 114.1, 118.3, 124.1, 127.5, 128.8, 130.9, 142.1, 152.1, 153.1, 159.0; LRMS (EI $\left.{ }^{+}\right) \mathrm{m} / \mathrm{z} 313\left(\mathrm{M}^{+}, 100\right), 255$ (10); HRMS $\left(\mathrm{EI}^{+}, \mathrm{M}^{+}\right) \mathrm{m} / \mathrm{z}$ calcd for $\mathrm{C}_{18} \mathrm{H}_{19} \mathrm{O}_{4} \mathrm{~N}$ 313.1314, found 313.1311.

6-Acetic acid-2,3,4,4'-tetramethoxy-biphenyl (26). To 6-acetonitrile-2,3,4,4'-tetramethoxy-biphenyl (3.34 g, $11.0 \mathrm{mmol})$ in a round bottom flask was added $45 \mathrm{~mL}$ of $40 \% \mathrm{KOH}$ and $45 \mathrm{~mL}$ of EtOH. The yellow solution was heated to $100{ }^{\circ} \mathrm{C}$ for $12 \mathrm{~h}$. After cooling to room temperature, the reaction was poured into a separatory funnel and washed twice with $50 \mathrm{~mL}$ portions of ether. The aqueous layer was acidified with conc. $\mathrm{HCl}$ and extracted with $50 \mathrm{~mL}$ of $\mathrm{CH}_{2} \mathrm{Cl}_{2}$ three times. The combined $\mathrm{CH}_{2} \mathrm{Cl}_{2}$ extracts were dried $\left(\mathrm{MgSO}_{4}\right)$, and evaporated to yield $2.88 \mathrm{~g}$ of a white solid (79\%) mp 144-146 ${ }^{\circ} \mathrm{C}$. IR $\left(\mathrm{CCl}_{4}\right) 3300$ (w), 3006 (m), 2958 (m), 2939 (m), 2835 (m), 1706 (s), 1489 (s), 1246 (s), 1107 (m); ${ }^{1} \mathrm{H}$ NMR (CDCl $\left.{ }_{3}\right) \delta 3.44$ (s, 2H), 3.58 (s, 3H), 3.84 (s, 3H), 3.89 (s, 3H), 3.90 (s, 3H), 6.66 (s, 1H), 6.93 (d, J=8.0, 2H), 7.14 (d, J=8.0, 2H), 10.9 (br, $1 \mathrm{H}) ;{ }^{13} \mathrm{C}$ NMR $\left(\mathrm{CDCl}_{3}\right) \delta 38.5,55.2,56.0,60.9,61.0,108.9,113.6,127.5,128.5,129.6,131.2,141.5,151.8,152.5,158.7,177.1$; LRMS (EI ${ }^{+}$) m/z 334 (M+ + H, 25), 333 (M+100), 319 (10), 287 (10), 242 (15); HRMS (EI ${ }^{+} \mathrm{M}^{+}$) m/z calcd for $\mathrm{C}_{18} \mathrm{H}_{21} \mathrm{O}_{6}$ 333.1338, found 333.1333.

2,3,4,4'-Tetramethoxy-9-phenanthrol (27). 6-Acetic acid-2,3,4,4'-tetramethoxy-biphenyl (1.00 g, $3.00 \mathrm{mmol})$ was stirred under argon in $12 \mathrm{~mL}$ of methanesulfonic acid for $2.5 \mathrm{~h}$ at room temperature. The reaction was then poured into $100 \mathrm{~mL}$ of 
ice water and extracted three times with $75 \mathrm{~mL}$ of ether. The combined ether extracts were dried $\left(\mathrm{MgSO}_{4}\right)$, and evaporated to yield a brown solid which was quickly purified via column chromatography (TLC $\mathrm{R}_{\mathrm{f}}=0.39$, 1:1 hexanes/EtOAc) to yield $707 \mathrm{mg}$ of an off white solid (75\%) mp 145-148 ${ }^{\circ} \mathrm{C}$ (decomp). IR ( $\left.\mathrm{CCl}_{4}\right) 3608$ (m), 3505 (w), 3006 (w), 2964 (w), 2935 (w),

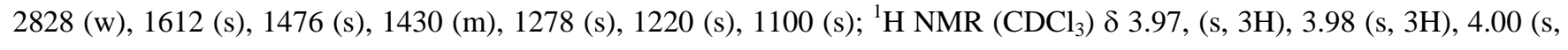
6H), 5.37 (s, 1H), 6.87 (s, 1H), 6.91 (s, 1H), 7.27-7.30 (d, J=9.6, 1H), 7.68 (s, 1H), 9.42 (s, J=9.6, 1H) ; ${ }^{13} \mathrm{C} \mathrm{NMR}\left(\mathrm{CDCl}_{3}\right) \delta$ 55.3, 55.8, 60.2, 61.3, 102.4, 103.5, 106.6, 115.3, 117.5, 125.6, 126.4, 128.4, 129.4, 141.0, 148.9, 151.9, 152.1, 157.2; LRMS $\left(\mathrm{EI}^{+}\right) \mathrm{m} / \mathrm{z} 315\left(\mathrm{M}^{+}+\mathrm{H}, 100\right), 284$ (15); HRMS $\left(\mathrm{EI}^{+}, \mathrm{M}^{+}+\mathrm{H}\right) \mathrm{m} / \mathrm{z}$ calcd for $\mathrm{C}_{18} \mathrm{H}_{19} \mathrm{O}_{5}$ 315.1233, found 315.1228.

2,3,4,4'-Tetramethoxy-9-(methoxymethoxy)-phenanthrene (28). 2,3,4,4'-Tetramethoxy-9-phenanthrol (611 mg, 1.94 mmol) was dissolved in $10 \mathrm{~mL}$ of $\mathrm{CH}_{2} \mathrm{Cl}_{2}$. To this solution was added $711 \mu \mathrm{L}$ (5.83 mmol) of chloromethylmethyl ether, followed by $633 \mu \mathrm{L}(5.83 \mathrm{mmol})$ of diisopropylethylamine. The reaction was stirred for $12 \mathrm{~h}$, at which time it was diluted with $50 \mathrm{~mL}$ of $\mathrm{CH}_{2} \mathrm{Cl}_{2}$ and washed with $50 \mathrm{~mL}$ of $1 \mathrm{M} \mathrm{HCl}, 50 \mathrm{~mL}$ of water, and $50 \mathrm{~mL}$ of brine. The organic phase was dried $\left(\mathrm{MgSO}_{4}\right)$, and evaporated to yield a yellow solid. Column chromatography (TLC $\mathrm{R}_{\mathrm{f}}=0.21$, 4:1 hexanes/EtOAc) yielded $459 \mathrm{mg}$ of a white solid (66\%) mp 109-110 ${ }^{\circ} \mathrm{C}$. IR ( $\left.\mathrm{CCl}_{4}\right) 3000$ (w), 3958 (m), 2932 (m), 2903 (w), 2841 (w), 1615 (s), 1498 (m), 1466 (s), 1272 (s), 1227 (s), 1155 (s), 1058 (s); ${ }^{1} \mathrm{H}$ NMR (CDCl $) \delta 3.58$ (s, 3H), 3.98 (s, 6H), 3.99 (s, 3H), 4.00 (s, 3H), 5.47 (s, 2H), 7.01 (s, 1H), 7.22 (s, 1H), 7.28 (d, J=9.2, 1H), 7.74 (s, 1H), 9.42 (d, J=9.2 , 1H) ; ${ }^{13} \mathrm{C}$ NMR $\left(\mathrm{CDCl}_{3}\right) \delta$ 55.3, 55.8, 56.2, 60.2, 61.3, 94.7, 102.6, 104.5, 106.6, 115.4, 117.1, 125.3, 127.5, 128.3, 129.4, 141.3, 150.3, 151.7, 151.9, 157.2; LRMS $\left(\mathrm{EI}^{+}\right) \mathrm{m} / \mathrm{z} 359\left(\mathrm{M}^{+}+\mathrm{H}, 50\right), 252$ (100), 136 (90); HRMS $\left(\mathrm{EI}^{+}, \mathrm{M}^{+}+\mathrm{H}\right) \mathrm{m} / \mathrm{z}$ calcd for $\mathrm{C}_{20} \mathrm{H}_{23} \mathrm{O}_{6}$ 359.1495, found 359.1508.

5,6-Dihydro-1,2,3,4'-tetramethoxy-5H-dibenzo[a,c]cyclohepten-7-one (29). 2,3,4,4'-Tetramethoxy-9-(methoxymethoxy)phenanthrene (286 mg, $0.798 \mathrm{mmol})$ and $18.1 \mathrm{mg}(0.0798 \mathrm{mmol})$ of benzyltriethylammonium chloride were vigorously stirred in $8 \mathrm{~mL}$ of $\mathrm{CHCl}_{3}$. To this suspension was added $1.6 \mathrm{~mL}$ of $50 \% \mathrm{NaOH}$ and the reaction was stirred for a further $6 \mathrm{~h}$ to consume all of the starting material. The reaction was then partitioned between $75 \mathrm{~mL}$ of $\mathrm{CH}_{2} \mathrm{Cl}_{2}$ and $50 \mathrm{~mL}$ of water. The aqueous layer was subsequently extracted with three $50 \mathrm{~mL}$ portions of $\mathrm{CH}_{2} \mathrm{Cl}_{2}$. The combined organic extracts were dried $\left(\mathrm{MgSO}_{4}\right)$ and filtered through a short pad of silica gel. Evaporation of the solvent yielded a yellow oil that was dissolved in $3 \mathrm{~mL}$ of THF. Isopropyl alcohol ( $3 \mathrm{~mL}$ ) was added, followed by $3 \mathrm{~mL}$ of $2 \mathrm{M} \mathrm{HCl}$. The yellow solution was heated to $100{ }^{\circ} \mathrm{C}$ for $12 \mathrm{~h}$. The THF and isopropyl alcohol were removed in vacuo, and $50 \mathrm{~mL}$ of ether and water were added. The aqueous phase was extracted twice with ether. The combined organic extracts were dried $\left(\mathrm{MgSO}_{4}\right)$ and filtered through a short pad of silica gel. Evaporation of the solvent yielded a yellow oil which was dissolved in $10 \mathrm{~mL}$ of EtOH. Sodium acetate (164 mg, $1.99 \mathrm{mmol}$ ) and palladium on carbon (5\%, $84.9 \mathrm{mg}, 0.0399 \mathrm{mmol}$ ) were added and the reaction mixture was stirred under 1 ATM of hydrogen for $1 \mathrm{~h}$. The reaction mixture was filtered, and poured into $25 \mathrm{~mL}$ of ether. The organic layer was washed with water $(25 \mathrm{~mL} x 2)$ and brine $(25 \mathrm{~mL})$. The ethereal phase was dried $\left(\mathrm{MgSO}_{4}\right)$, and evaporated to yield a colorless oil. Column chromatography (TLC $\mathrm{R}_{\mathrm{f}}=0.15$, 4:1 hexanes/EtOAc) yielded a colorless oil, which crystallized on standing to provide $139 \mathrm{mg}$ of white crystals (53\%, 3 steps) mp 135-136 ${ }^{\circ} \mathrm{C}$ (lit. $134-135{ }^{\circ} \mathrm{C}$ ) ${ }^{6}$ The ${ }^{1} \mathrm{H}$ NMR matched that reported by Lee and coworkers. IR $\left(\mathrm{CCl}_{4}\right) 3006$ (w), 2961 (m), 2932 (s), 2861 (w), 2832 (m), 1686 (s), 1605 (s), 1489 (s), 1408 (s), 1104 (s); ${ }^{13} \mathrm{C}$ NMR $\left(\mathrm{CDCl}_{3}\right) \delta$ 30.5, 49.5, 56.2, 57.1, 61.2, 61.9, 109.2, 111.5, 117.8, 118.5, 119.8, 120.2, 127.1, 


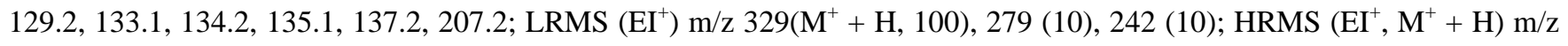
calcd for $\mathrm{C}_{19} \mathrm{H}_{21} \mathrm{O}_{5}$ 329.1389, found 329.1391.

$\boldsymbol{N}$-Acetylcolchinol methyl ether (2). Title compound was prepared from $114 \mathrm{mg}$ (0.347 mmol) of 5,6-dihydro-1,2,3,4'tetramethoxy-5H-dibenzo[a,c]cyclohepten-7-one according to the reductive amination/acylation protocol of Wulff and coworkers. ${ }^{4}$ Column chromatography (TLC $\mathrm{R}_{\mathrm{f}}=0.2740 \%$ acetone/pentane) yielded $78.7 \mathrm{mg}$ (61\%) of a white solid mp 203$204{ }^{\circ} \mathrm{C}$ (lit. 204-205 ${ }^{\circ} \mathrm{C}$ ). ${ }^{6}$ In $\mathrm{CDCl}_{3}$, two atropisomers were observed in approximately a 5:2 ratio, however, only one isomer is observed in DMSO. IR $\left(\mathrm{CCl}_{4}\right) 3447$ (m), 3000 (w), 2929 (m), 2861 (w), 2838 (w), 1699 (s), 1686 (s), 1485 (s), 1246 (m), 1110 (m); ${ }^{1} \mathrm{H}$ NMR (DMSO) $\delta$ 1.81-1.89 (m, 2H), 1.88 (s, 3H), 2.00-2.19 (m, 2H), 3.46 (s, 3H), 3.77 (s, 3H), 3.79 (s, 3H), 3.82 (s, 3H), 4.48-4.56 (m, 1H), 6.77 (s, 1H), 6.88 (s, 1H), 7.09 (br, 1H, $\mathrm{D}_{2} \mathrm{O}$ exchangeable) 7.24 (d, J=8.4, 1H), 8.38 (d, $J=8.4,1 \mathrm{H}$ ); ${ }^{13} \mathrm{C}$ NMR (DMSO) $\delta$ 23.5, 31.0, 49.0, 55.8, 56.7, 61.4, 61.4, 80.1, 108.9, 110.3, 111.6, 125.2, 127.0, 131.4, 135.6, 141.4, 142.7, 151.2, 153.0, 159.2, 169.2; LRMS (EI $\left.I^{+}\right) \mathrm{m} / \mathrm{z} 372\left(\mathrm{M}^{+}+\mathrm{H}, 100\right), 314$ (10), 313 (40); HRMS (EI $\mathrm{H}^{+}+$ H) $\mathrm{m} / \mathrm{z}$ calcd for $\mathrm{C}_{21} \mathrm{H}_{25} \mathrm{NO}_{5}$ 372.1811, found 372.1812. The ${ }^{1} \mathrm{H}$ NMR spectral data matched that reported by Lee and coworkers. ${ }^{6}$

\section{References}

(1) Still, W. C.; Kahn, M.; Mitra, A. Journal of Organic Chemistry 1978, 43, 2923-2925.

(2) Yamada, K.; Kurokawa, T.; Tokuyama, H.; Fukuyama, T. J. Am. Chem. Soc. 2003, 125, 6630-6631.

(3) Coburn, T. T.; Jones, W. M. J. Am. Chem. Soc. 1974, 96, 5218-5227.

(4) Vorogushin, A. V.; Predeus, A. V.; Wulff, W. D.; Hansen, H.-J. J. Org. Chem. 2003, 68, 5826-5831.

(5) Leblanc, M.; Fagnou, K. Org. Lett. 2005, 7, 2849-2852.

(6) Guan, J.; Zhu, X.-K.; Brossi, A.; Tachibana, Y.; Bastow, K. F.; Verdier-Pinard, P.; Hamel, E.; McPhail, A. T.; Lee, K.-H. Collect. Czech. Chem. Commun. 1999, 64, 217228. 


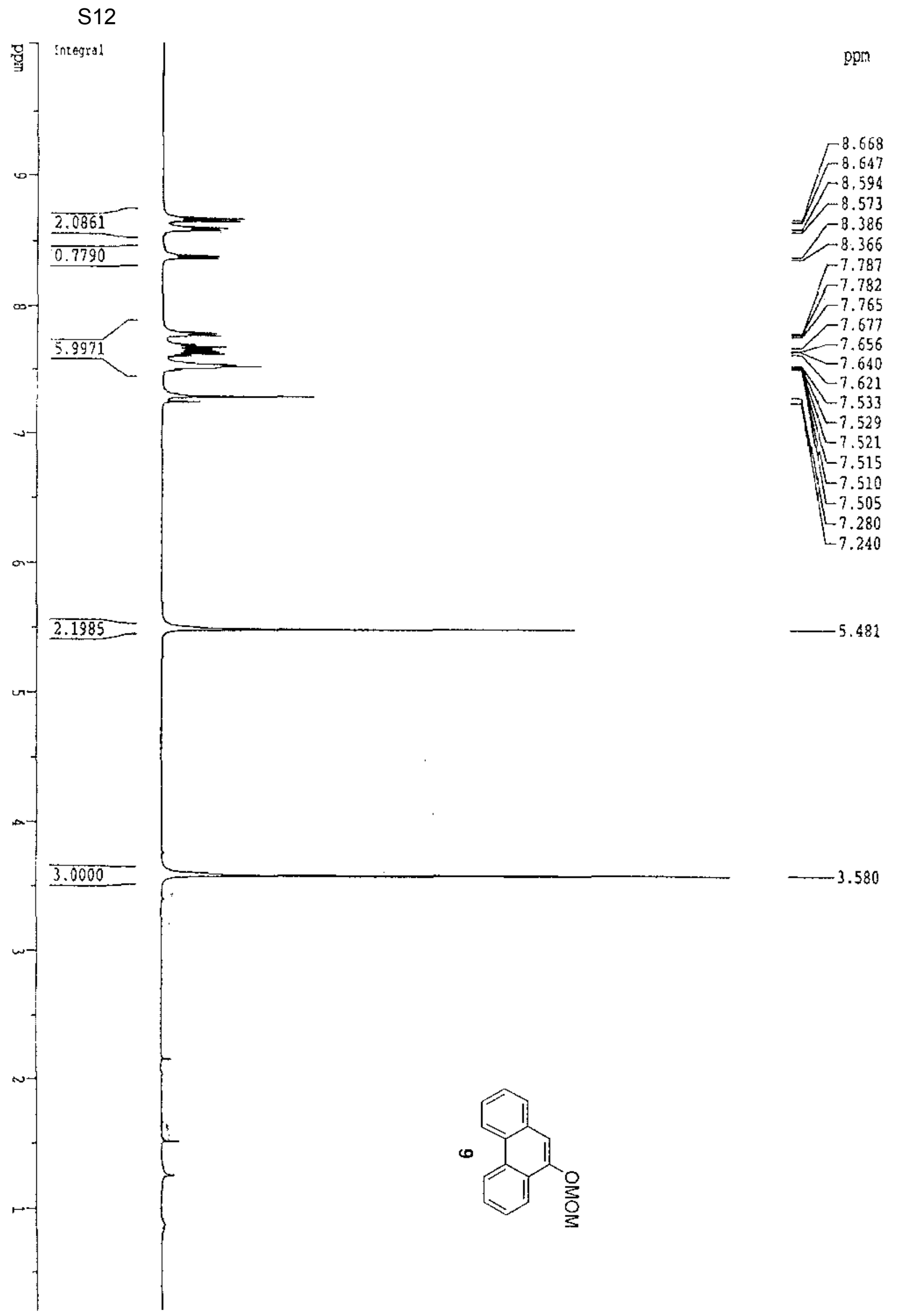




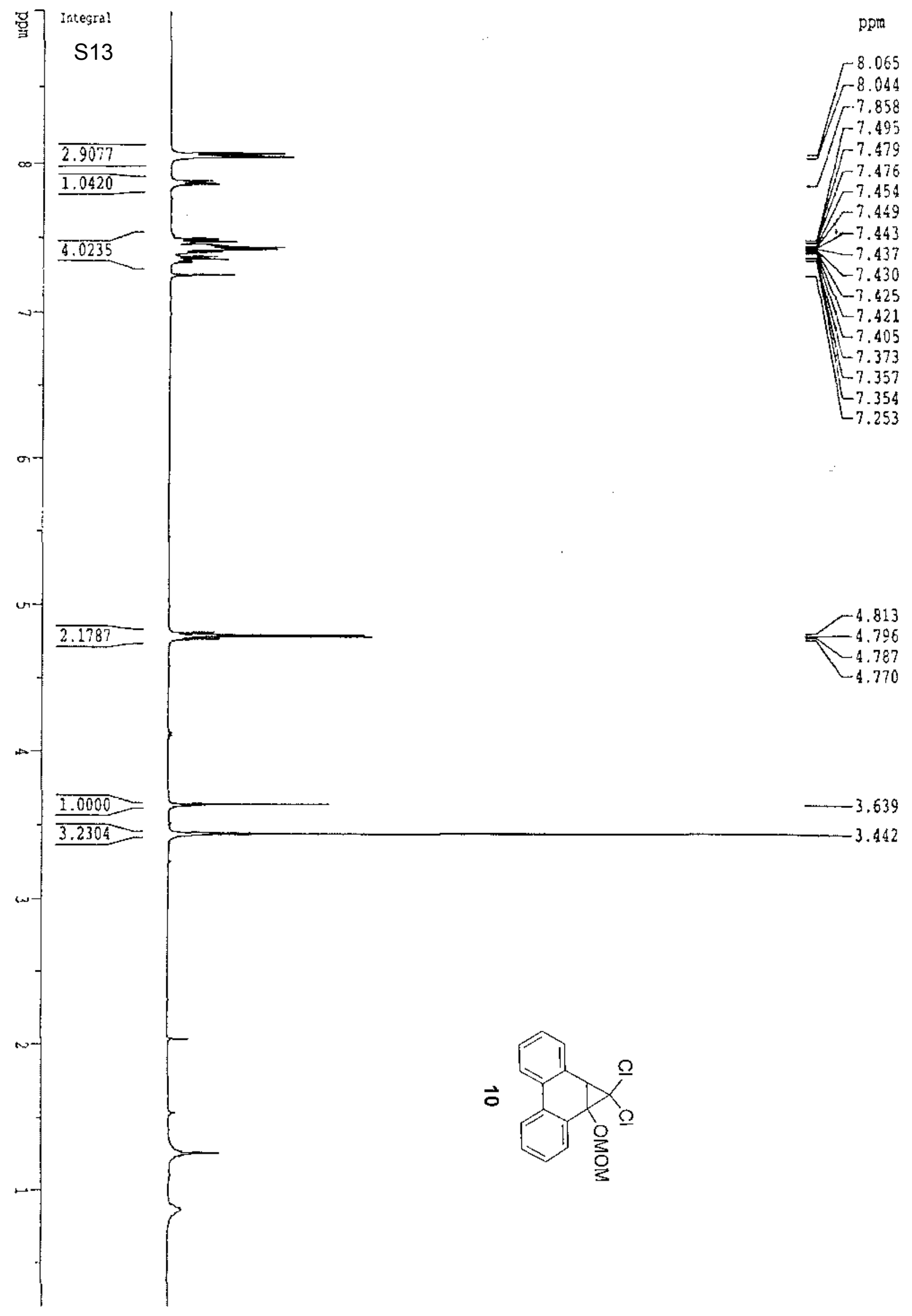




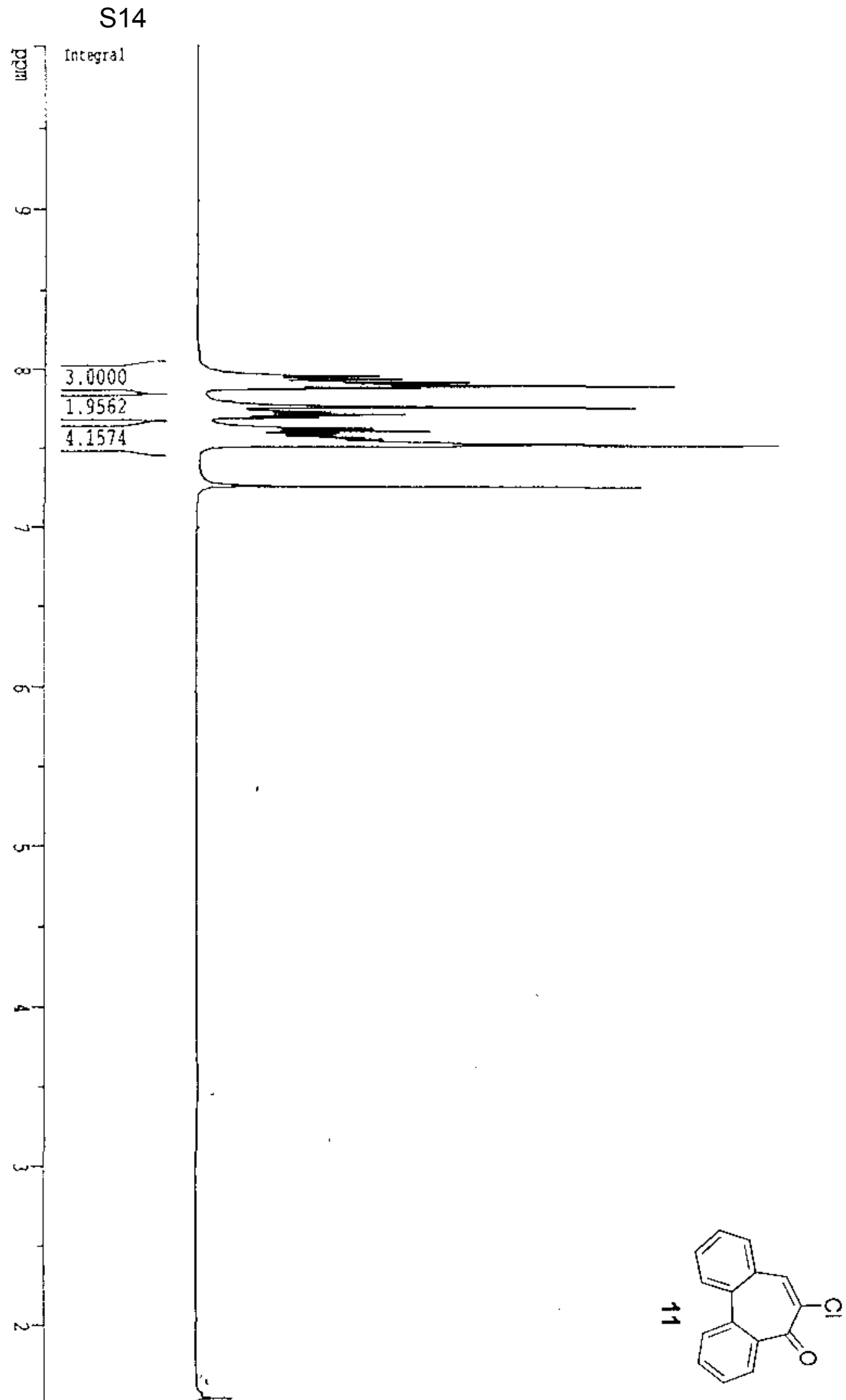




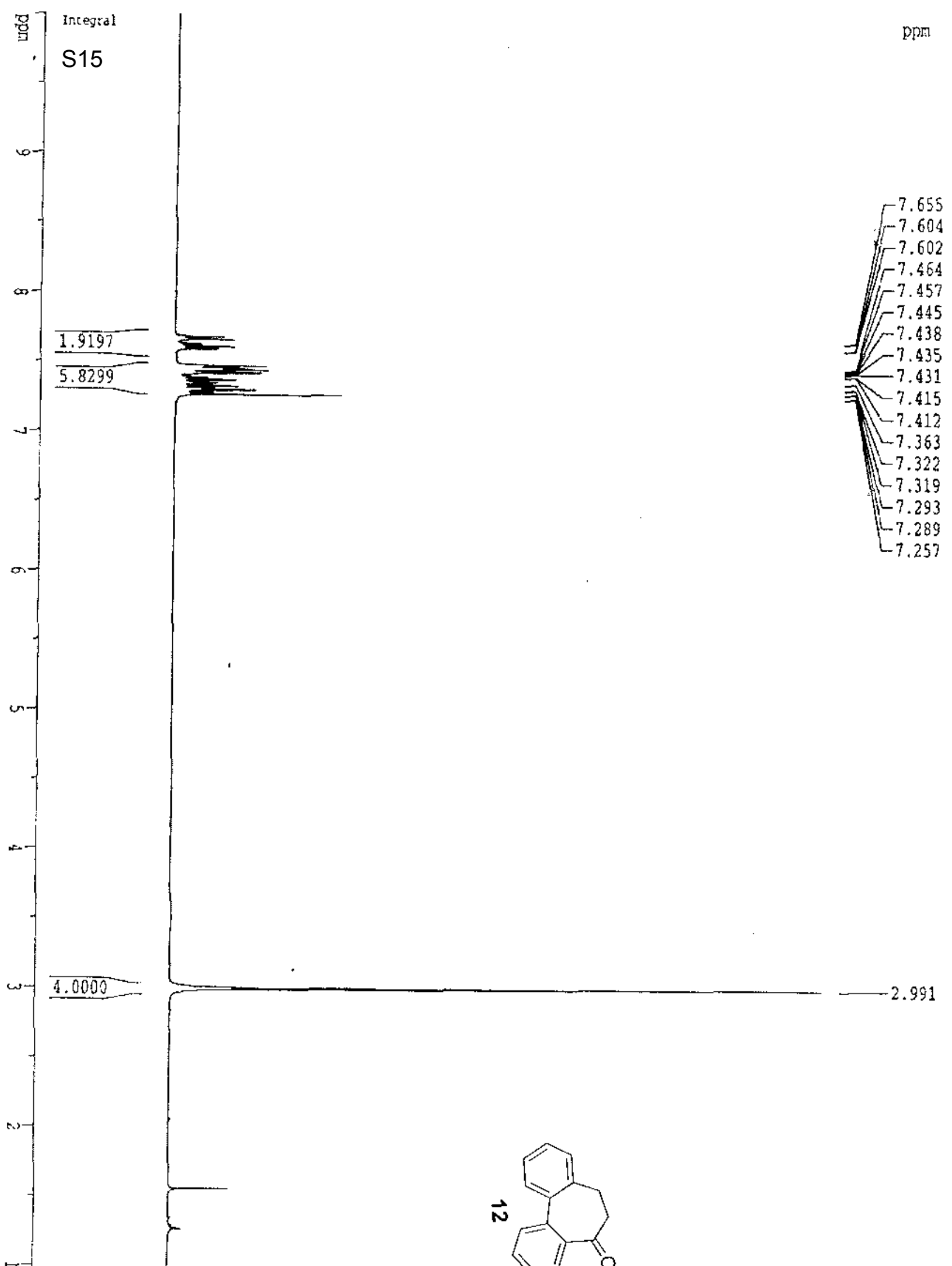




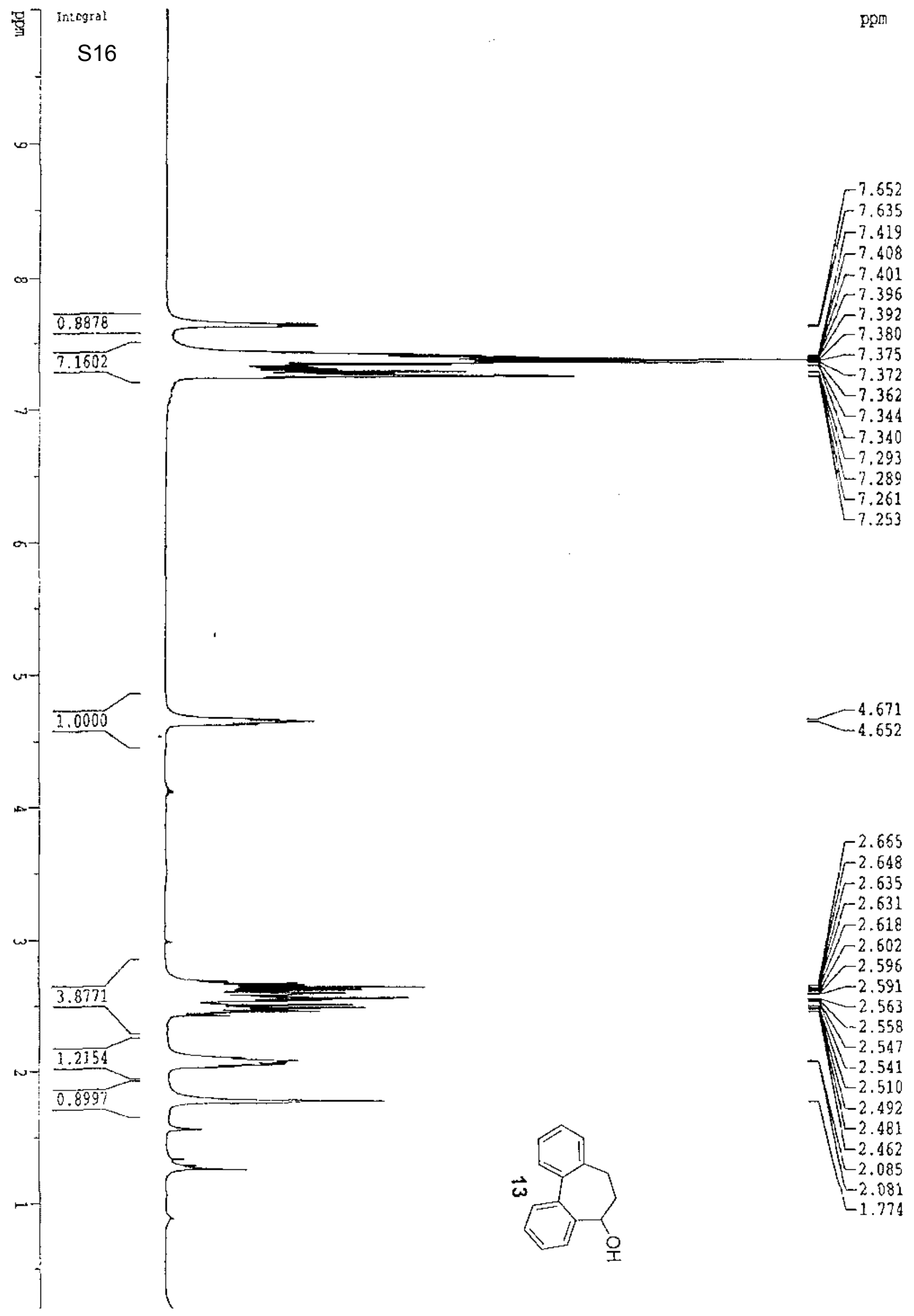




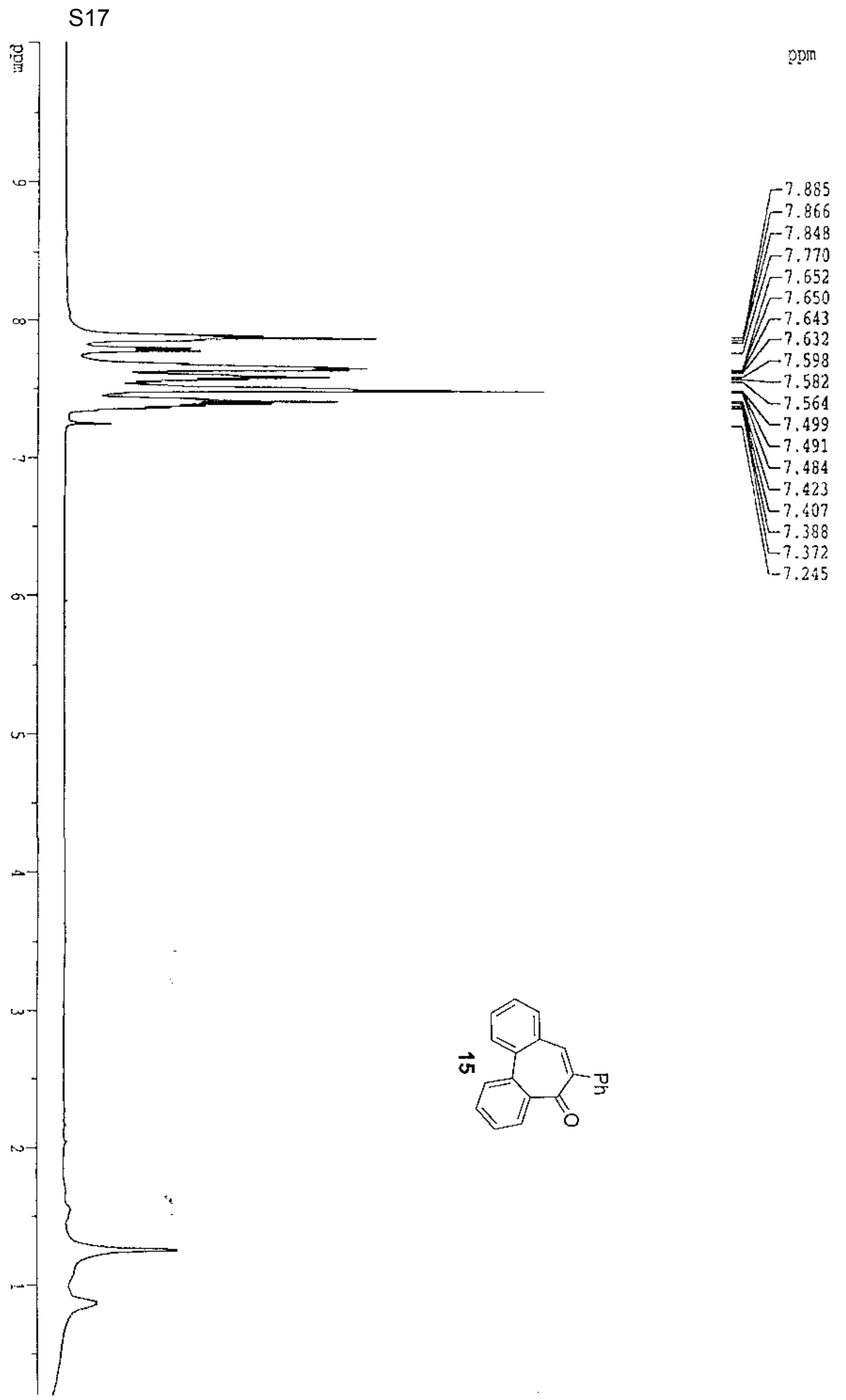




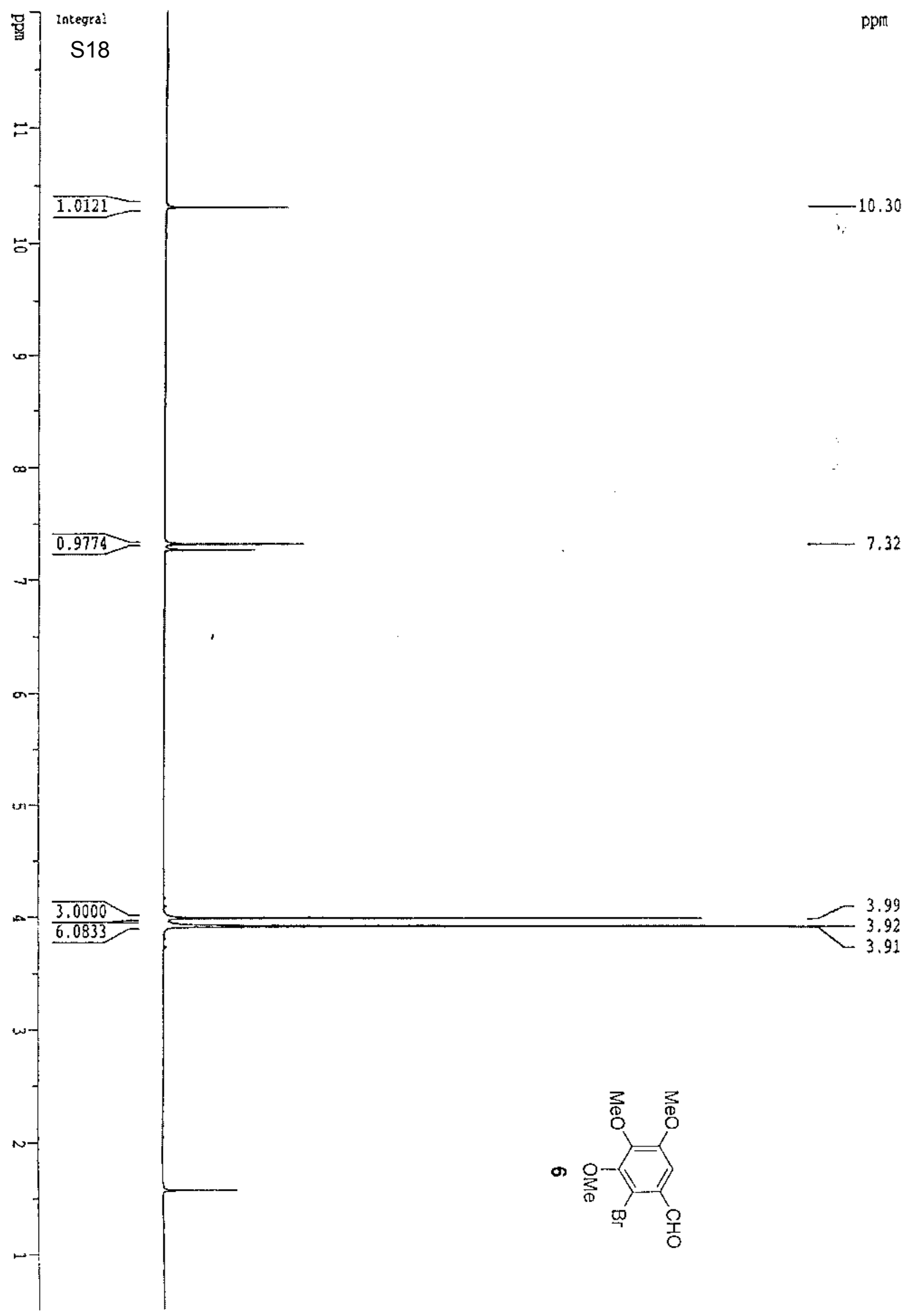




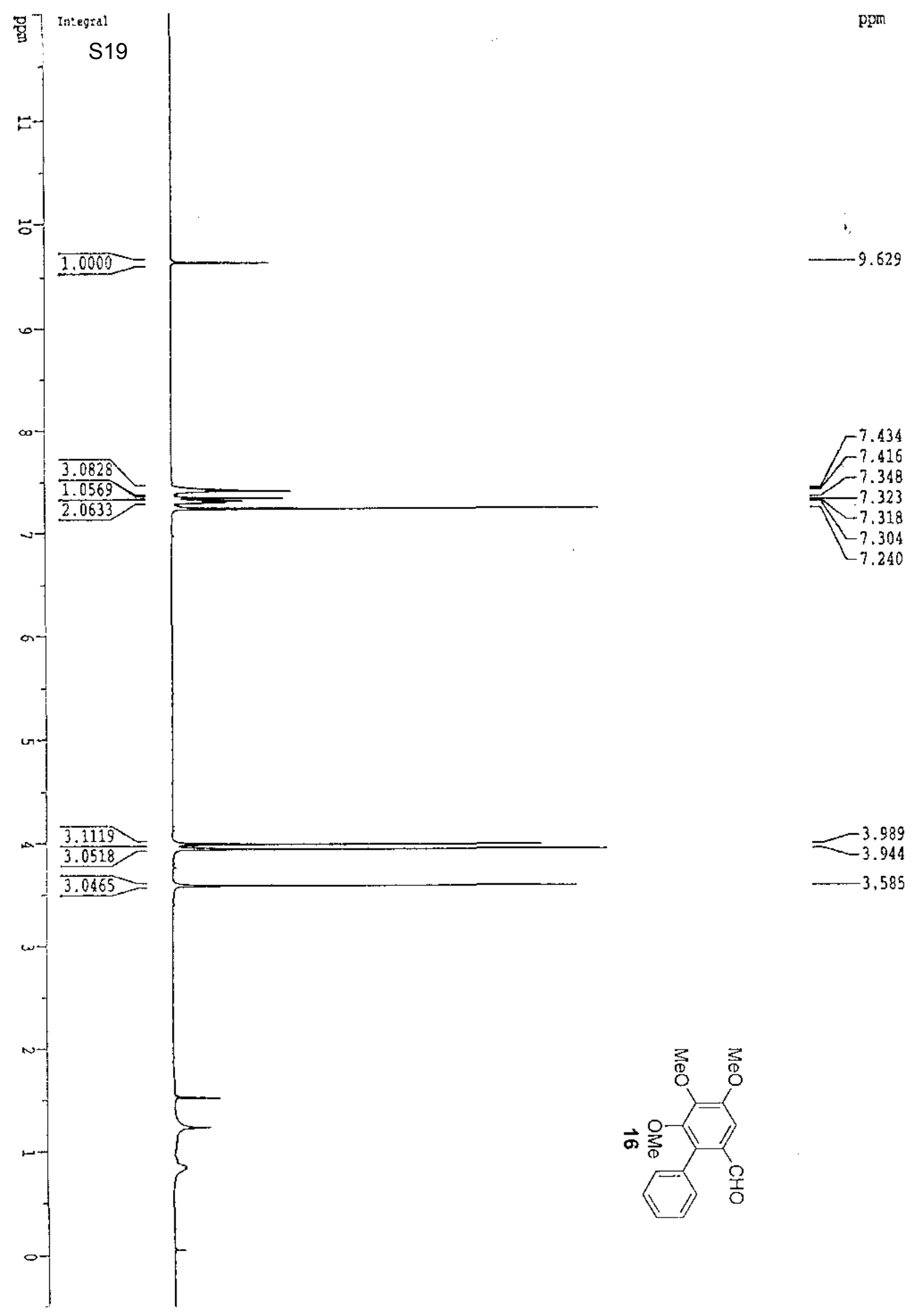




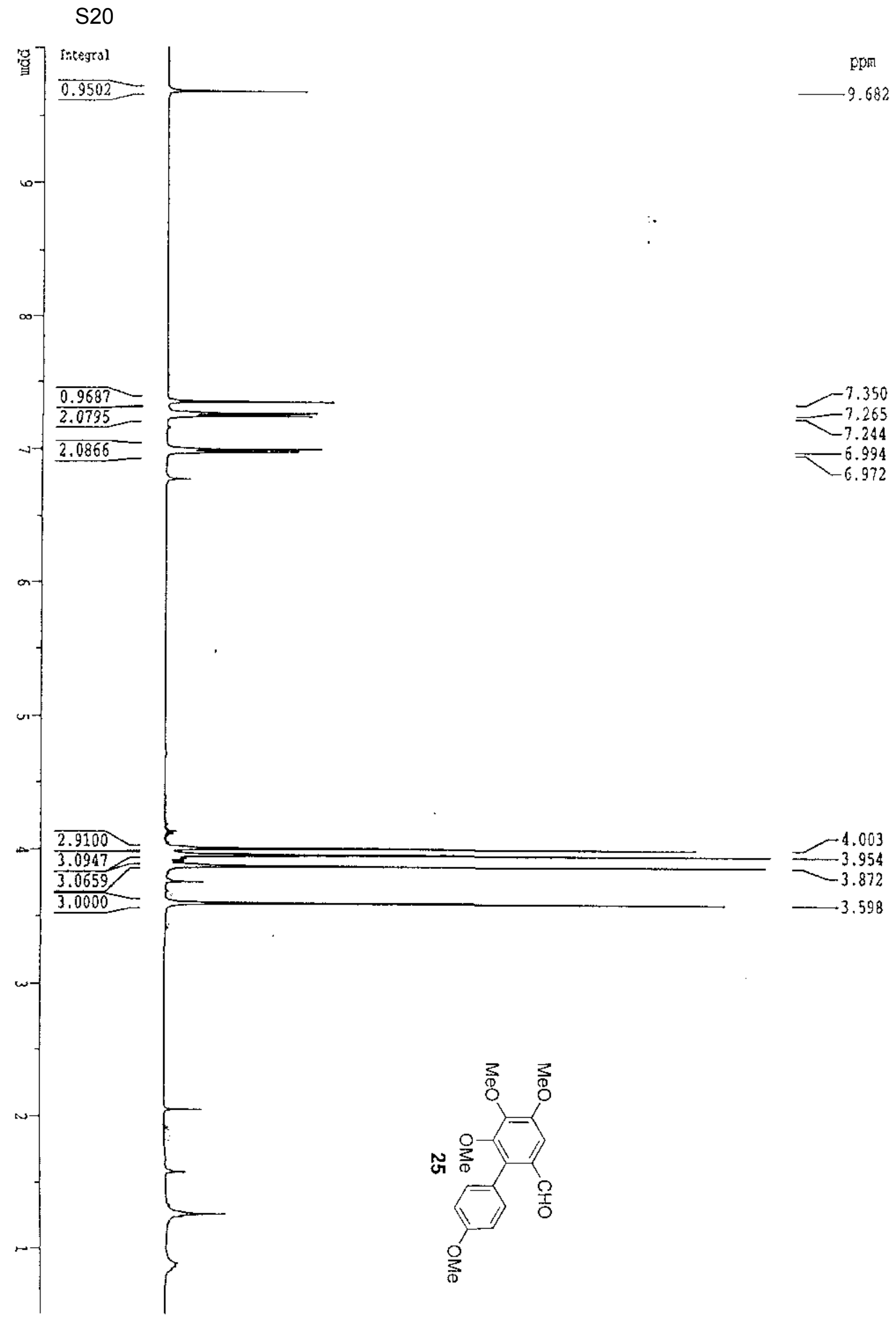




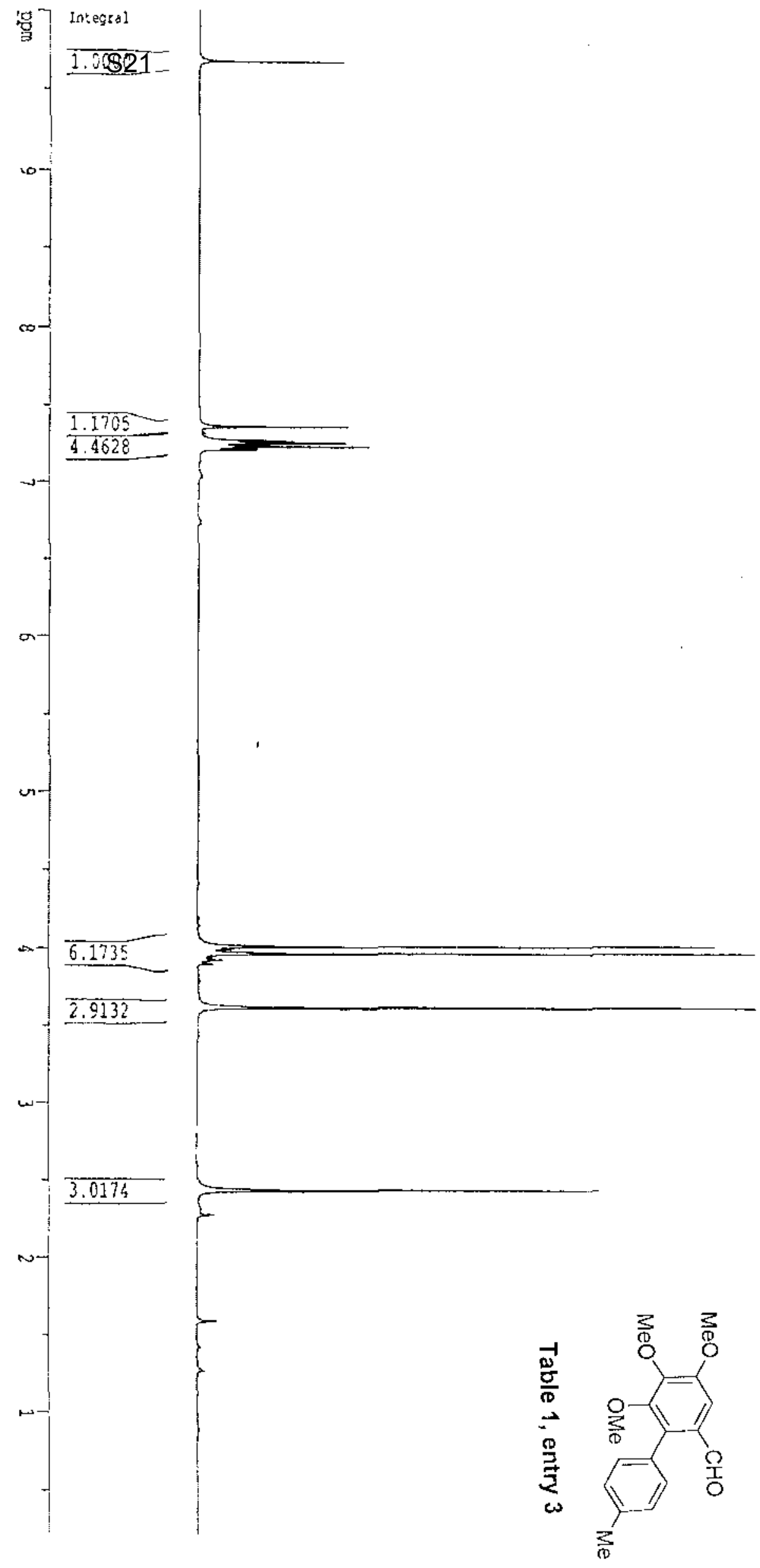

,

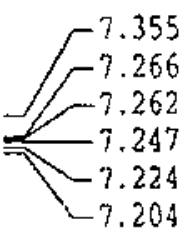

$=-4.002$

3.956

$-3.608$

$-2.4 \hat{2} 7$ 


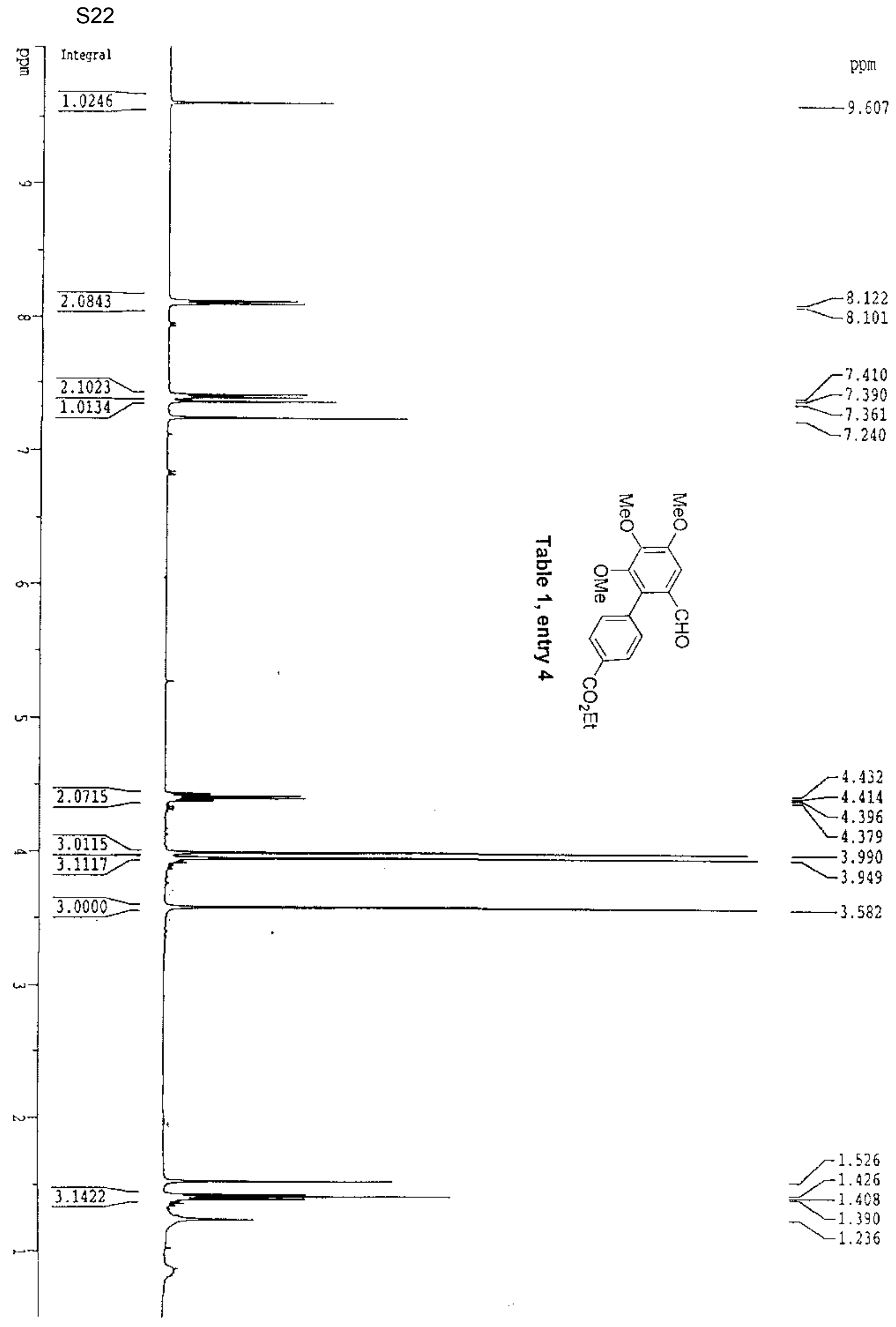




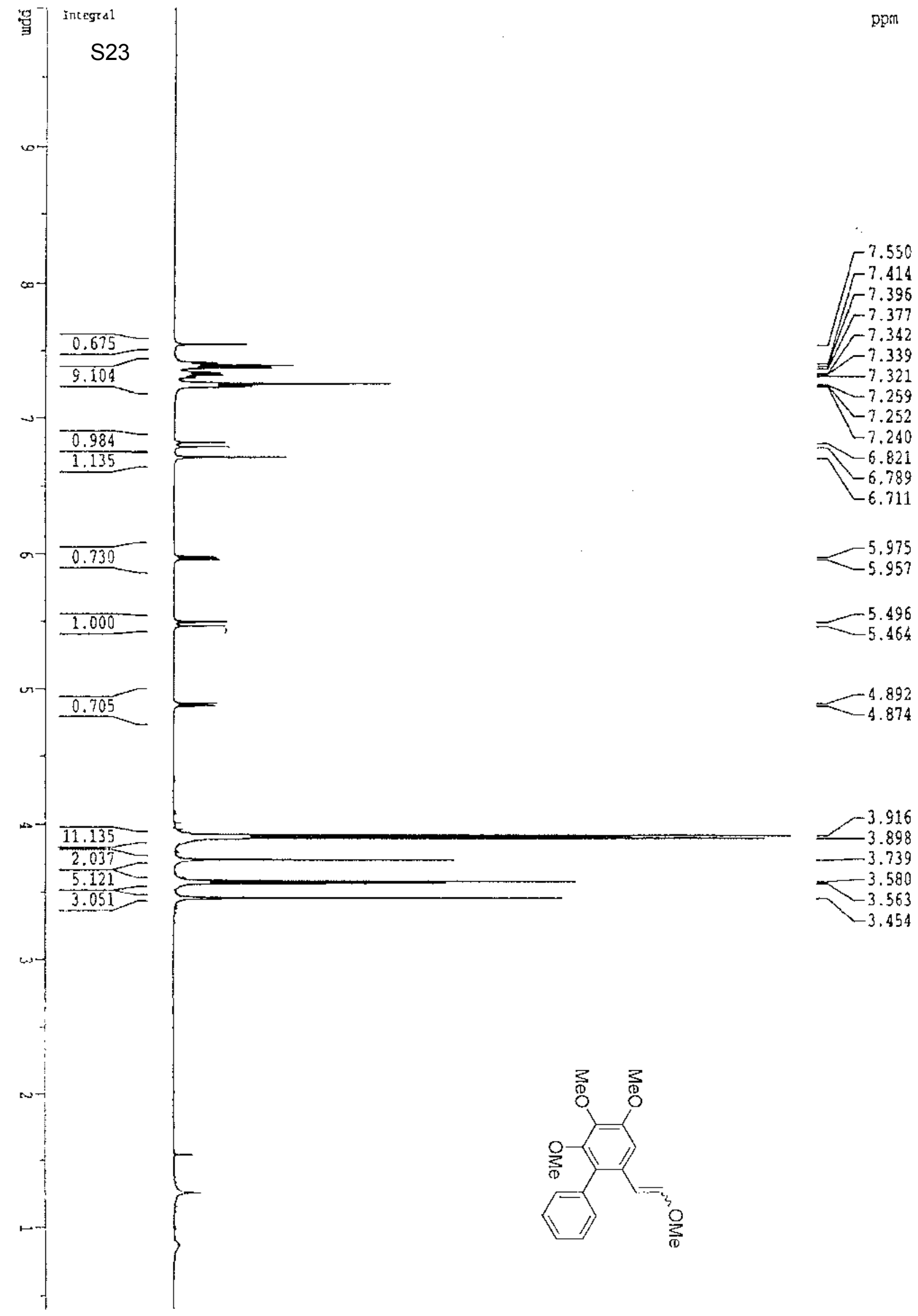




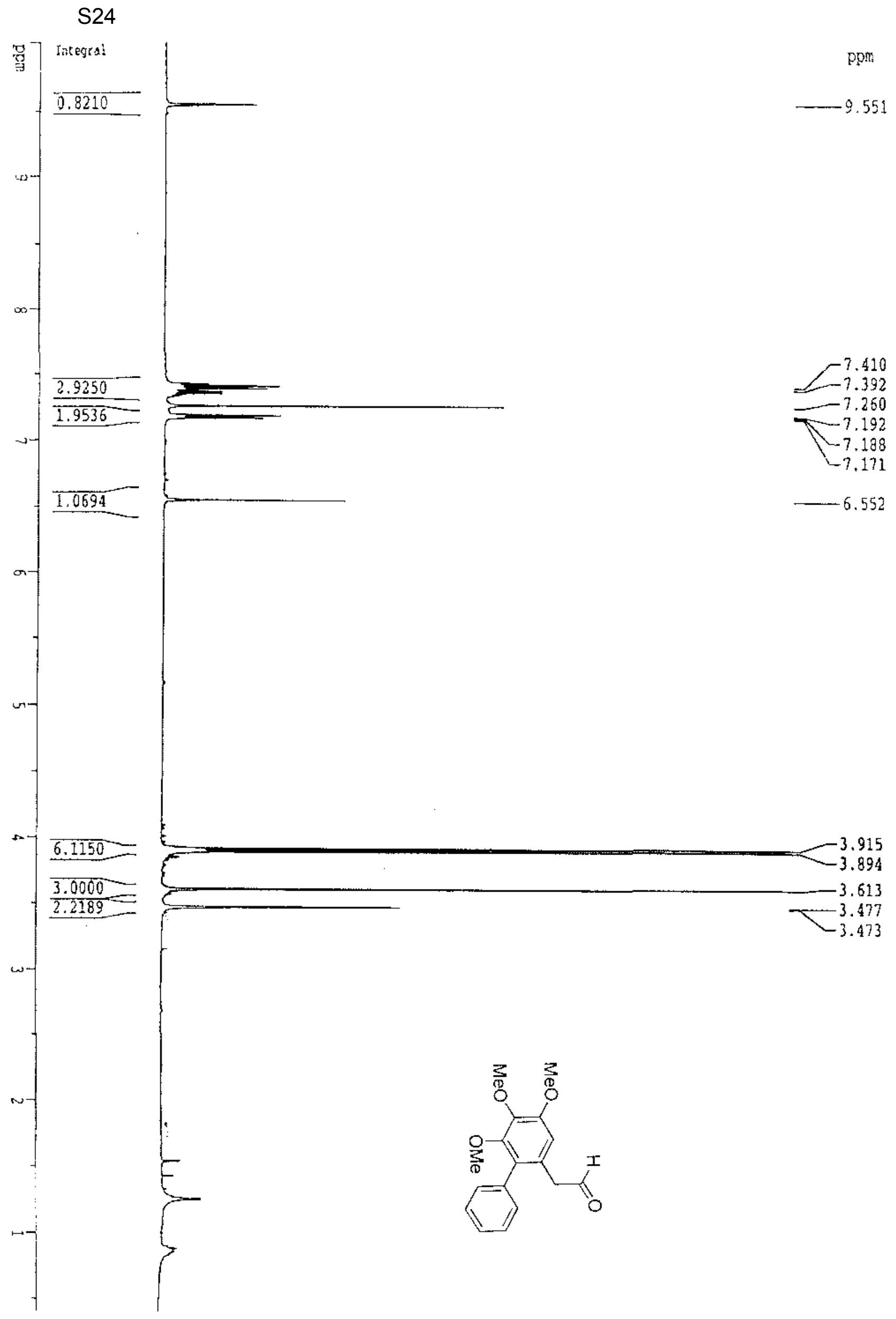




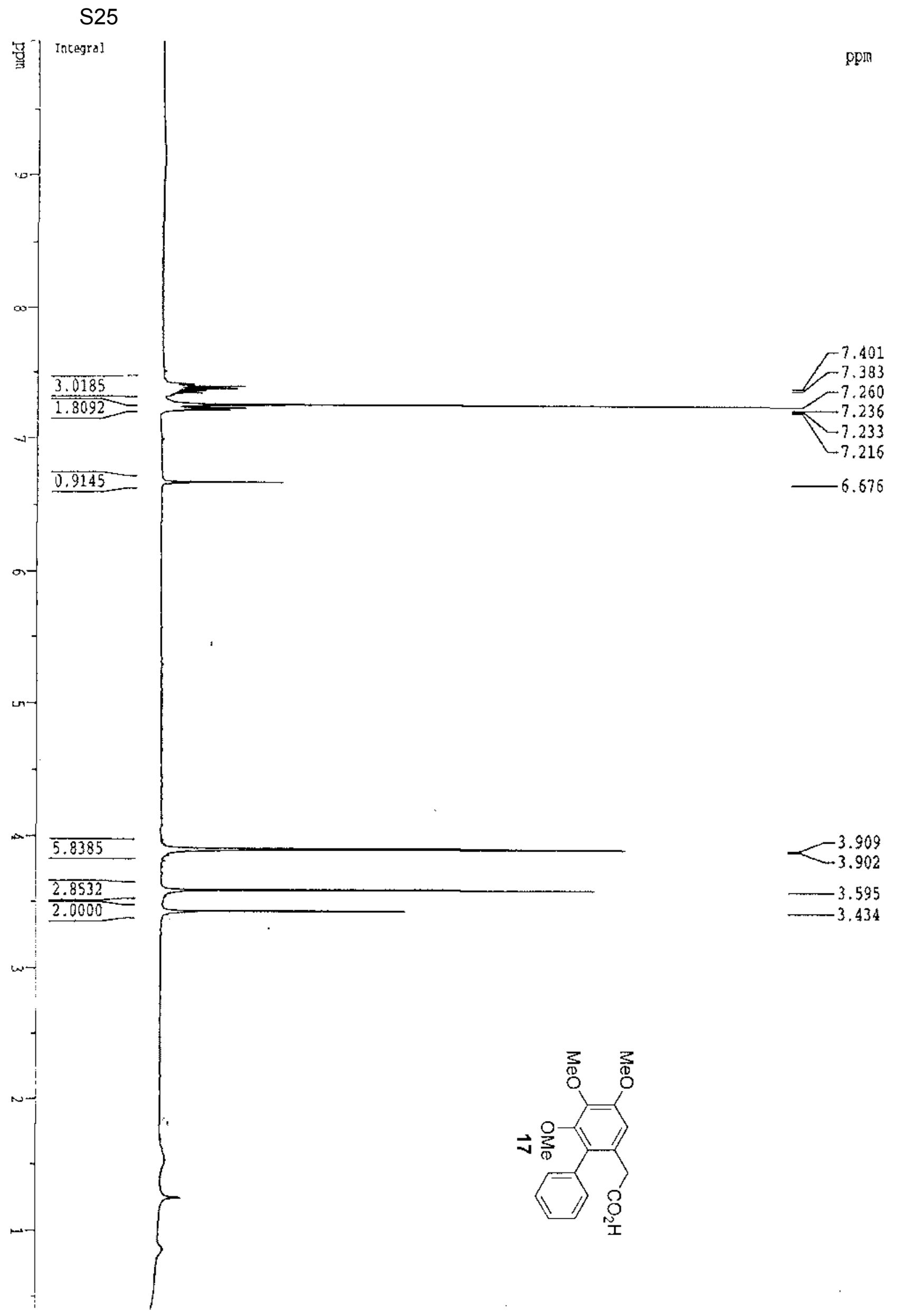




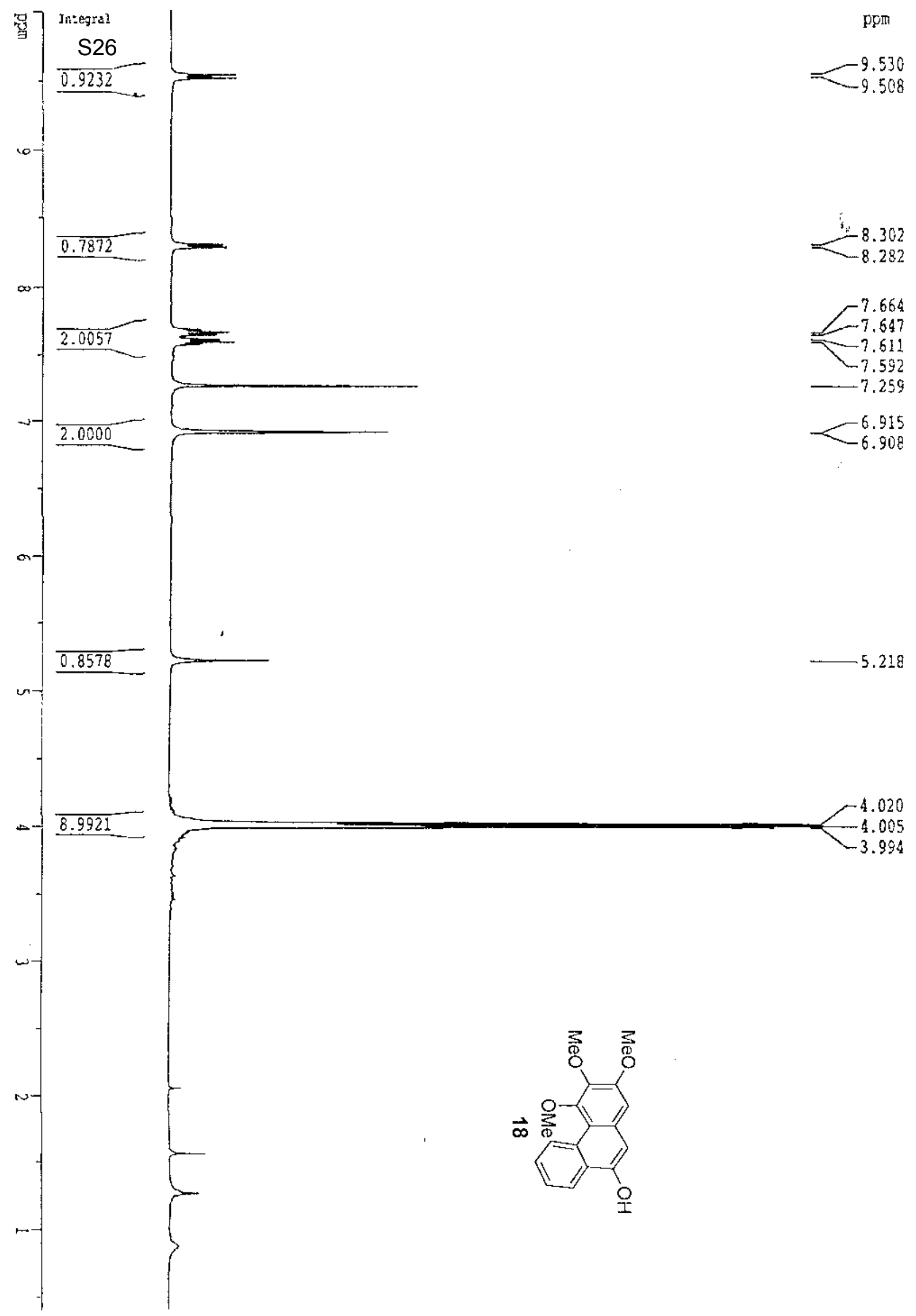




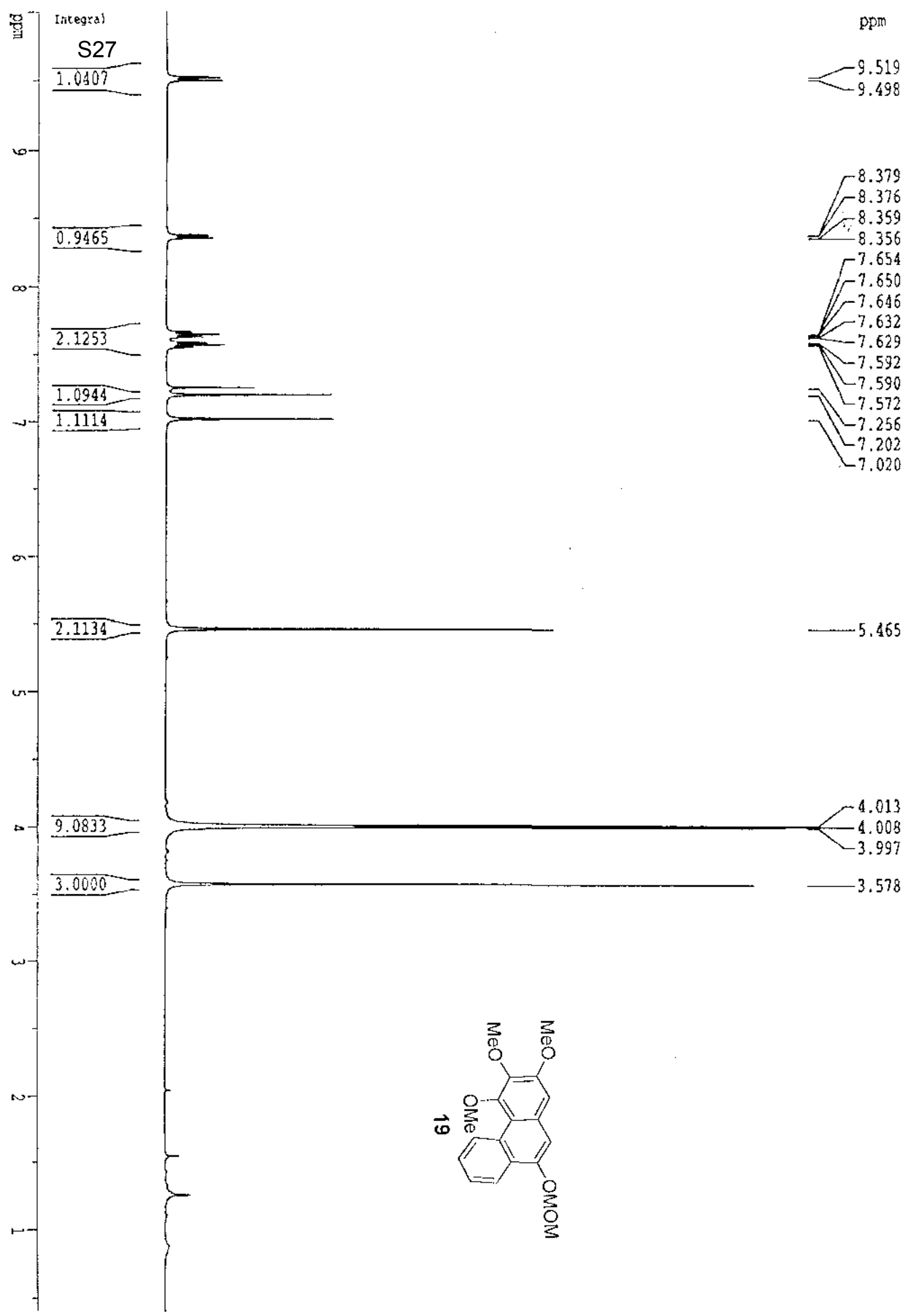




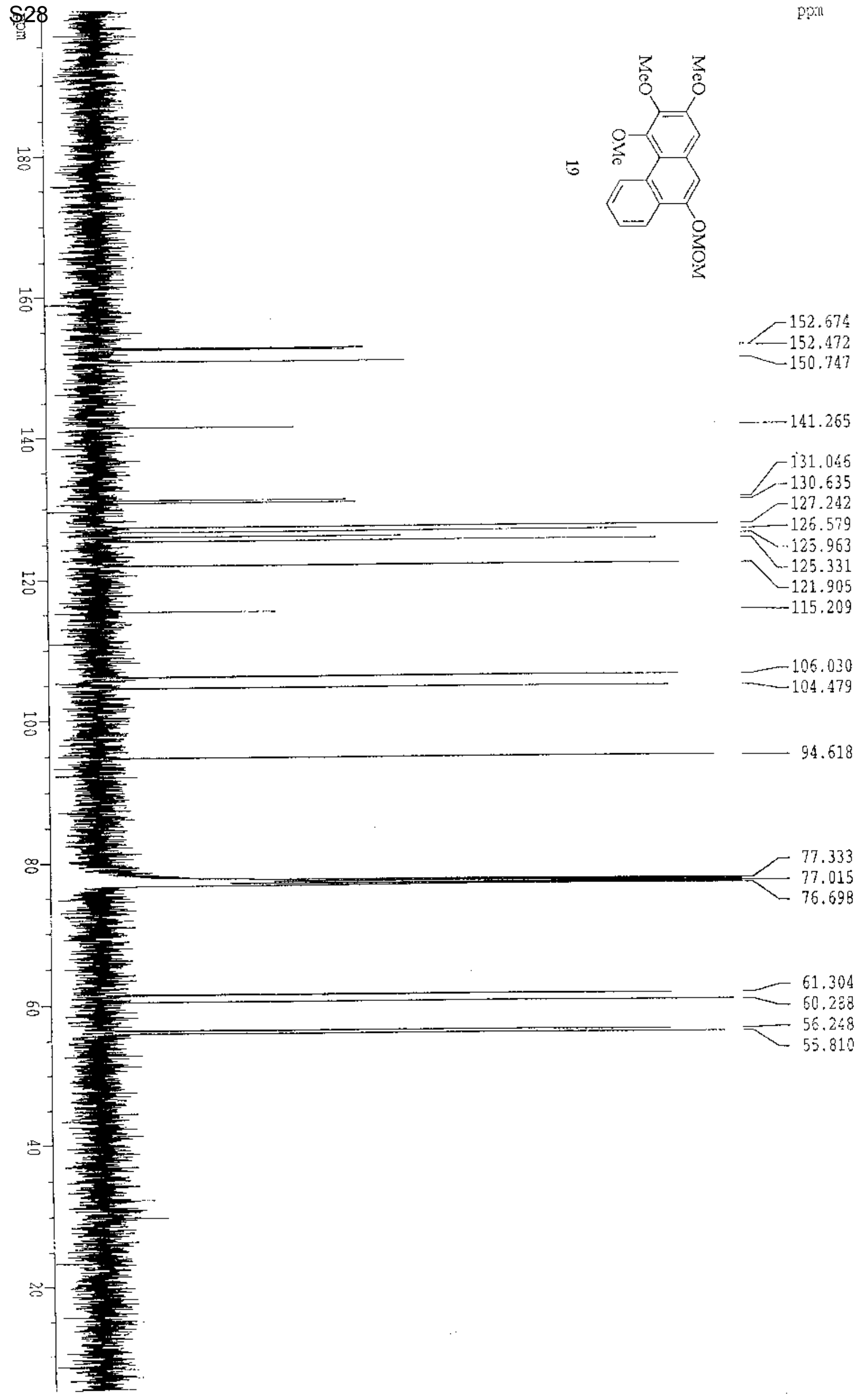



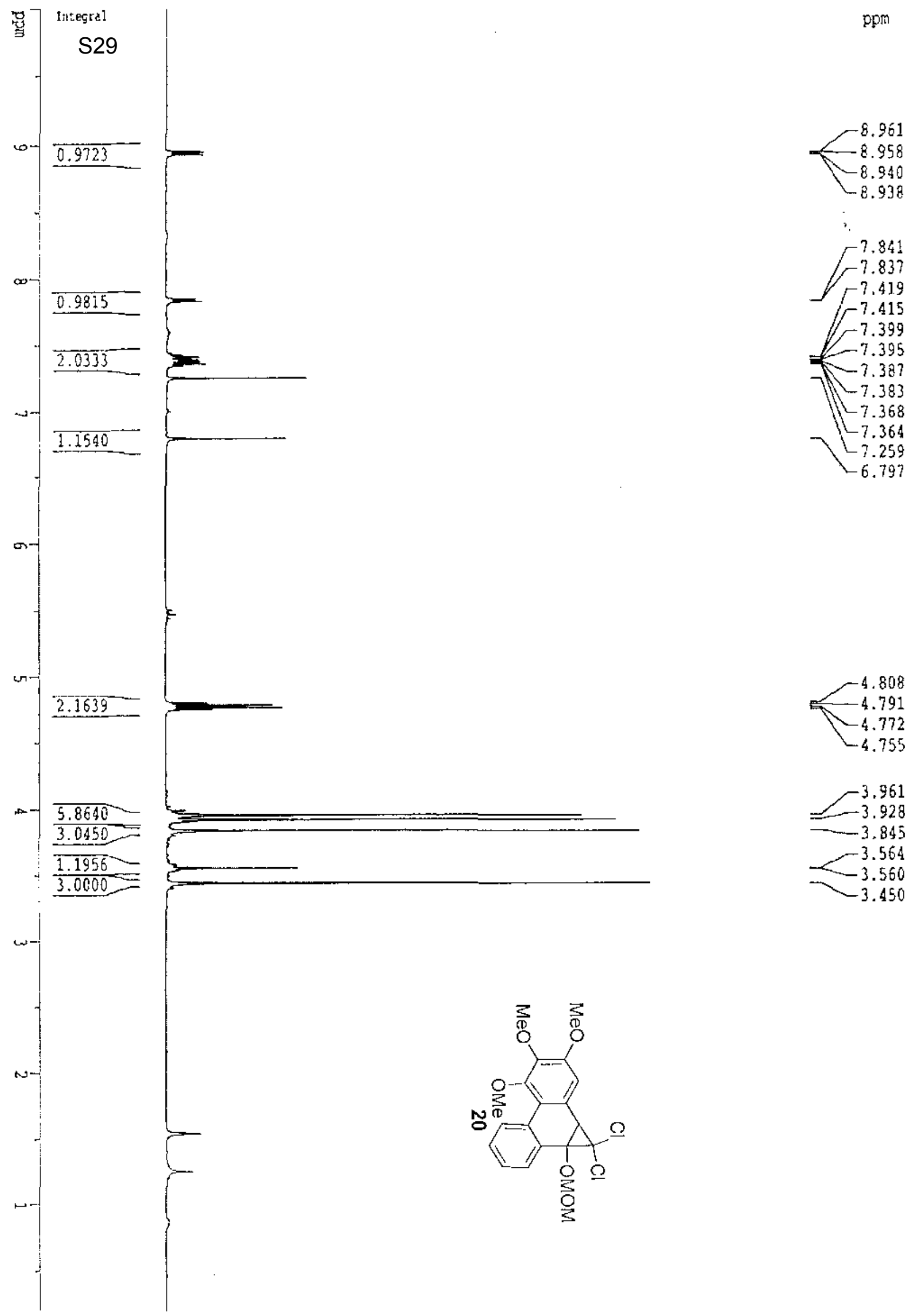

$-8.940$

$-8.938$

$-7.841$

$-7.837$

$\Gamma^{7.419}$

7.415

$-7.399$

$-7.395$

$-7.387$

$-7.383$

$-7.368$

$L_{7.364}$

$-7.259$

$-6.797$

$-4.808$

4.791

$-4.772$

$-4.755$

$-3.961$

$-3.928$

-3.845
-3.564

$-3.564$

$-3.560$

$-3.450$ 


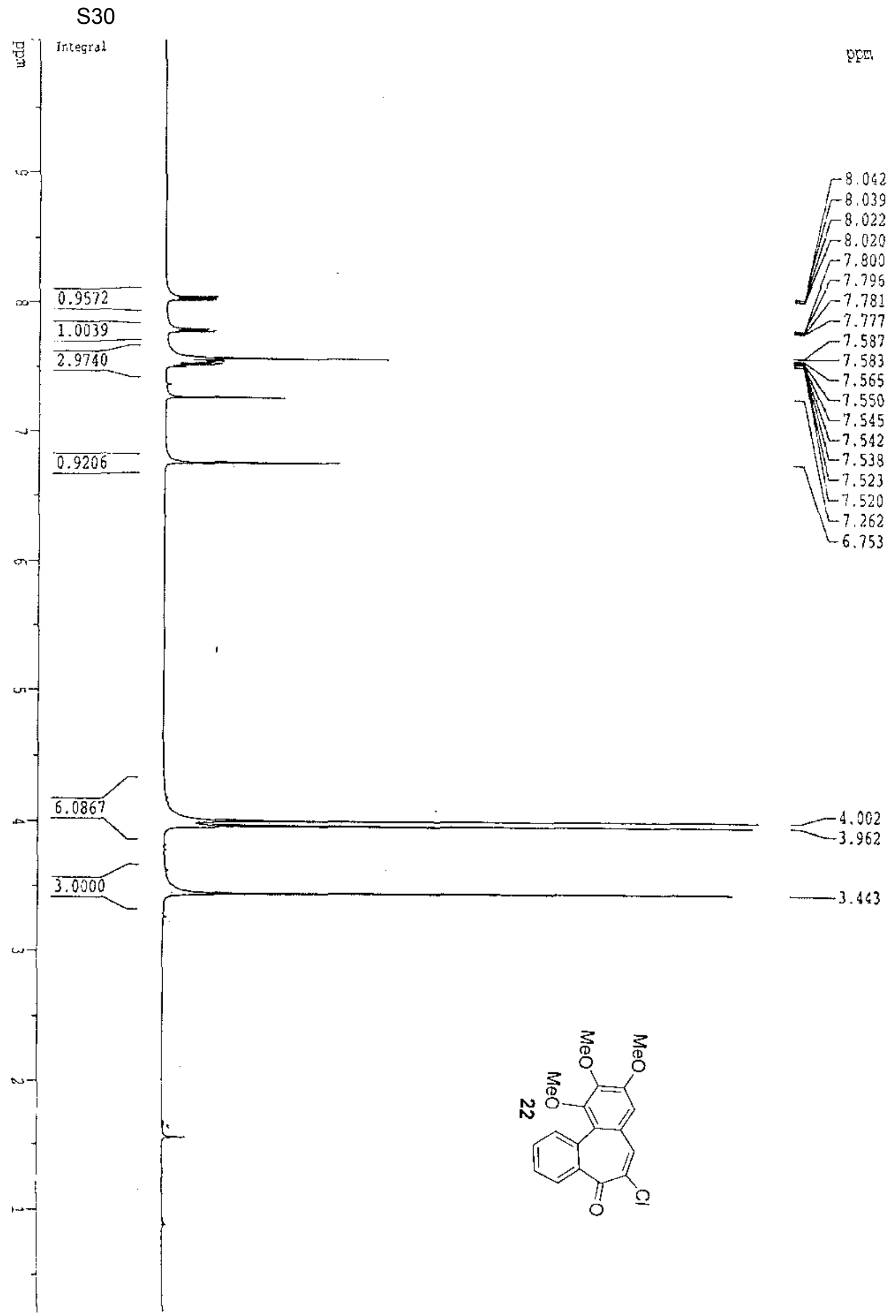




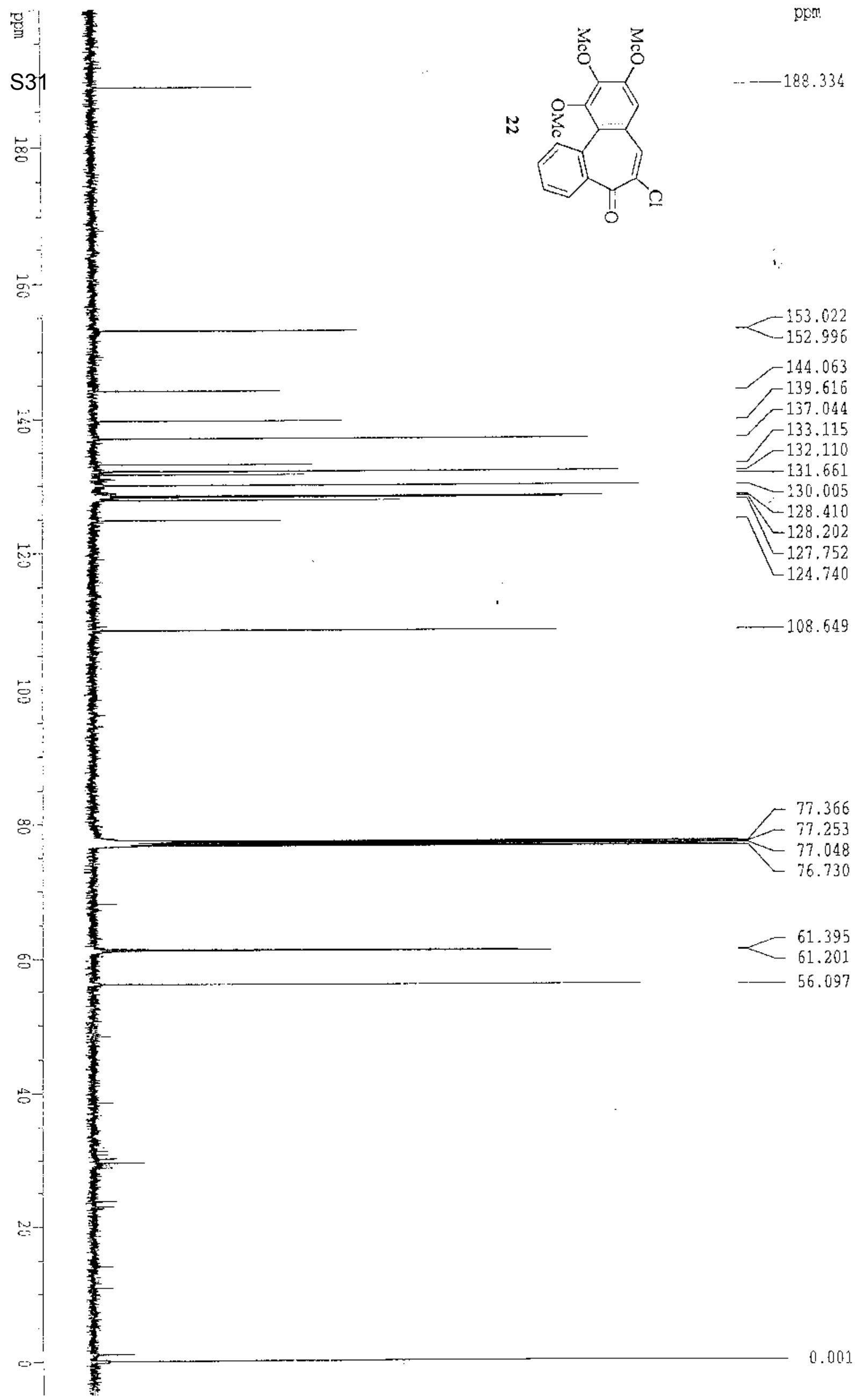




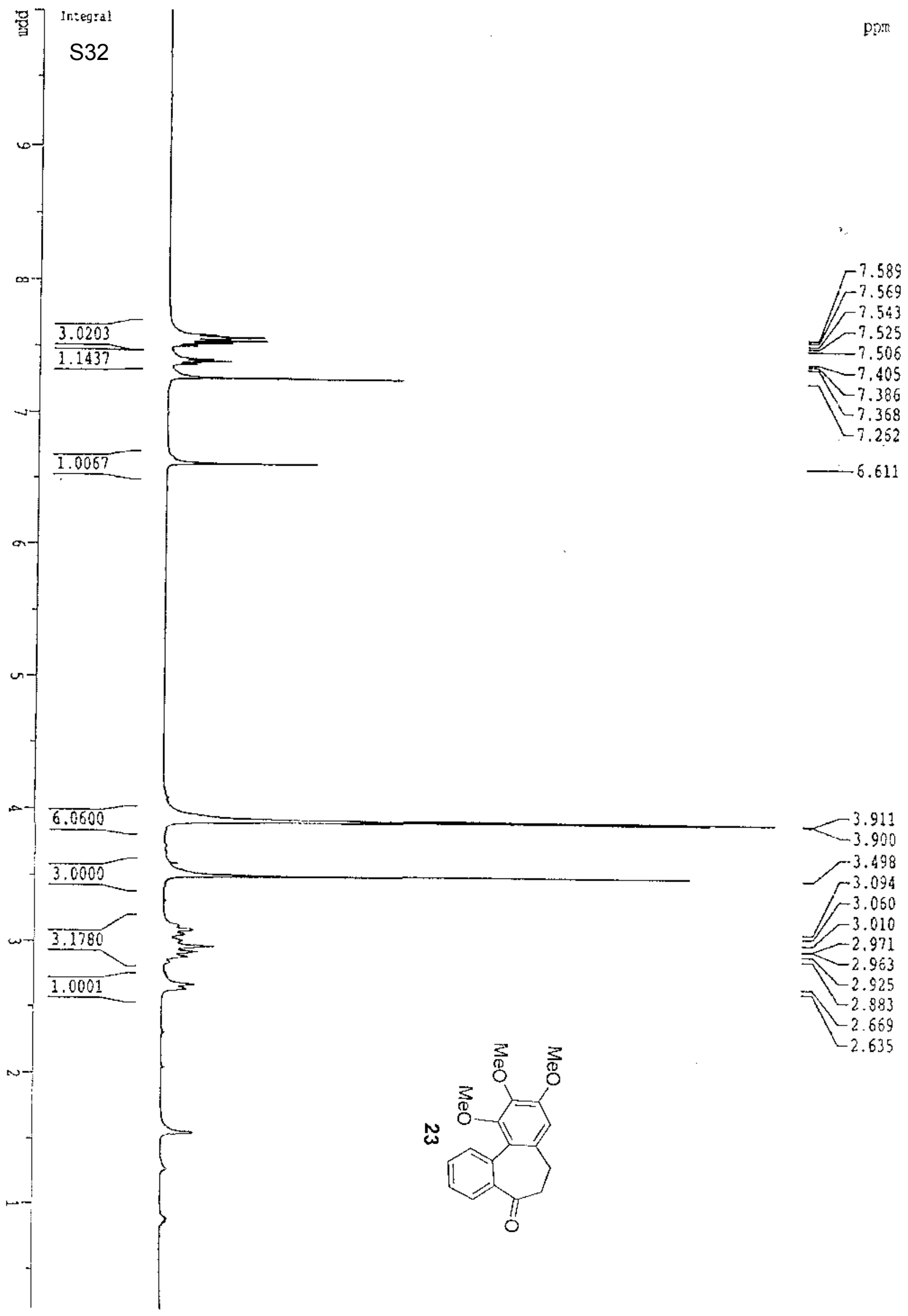




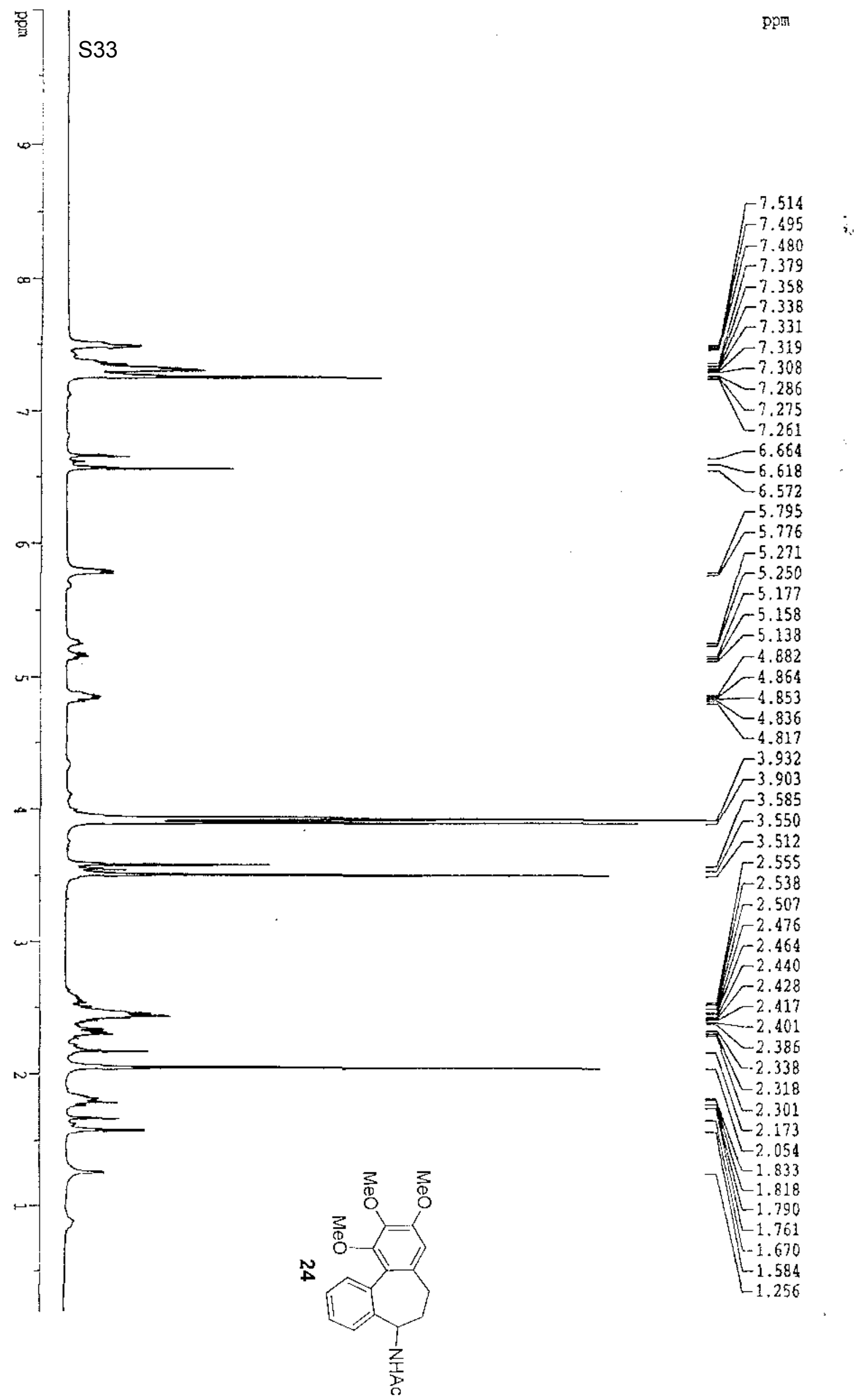




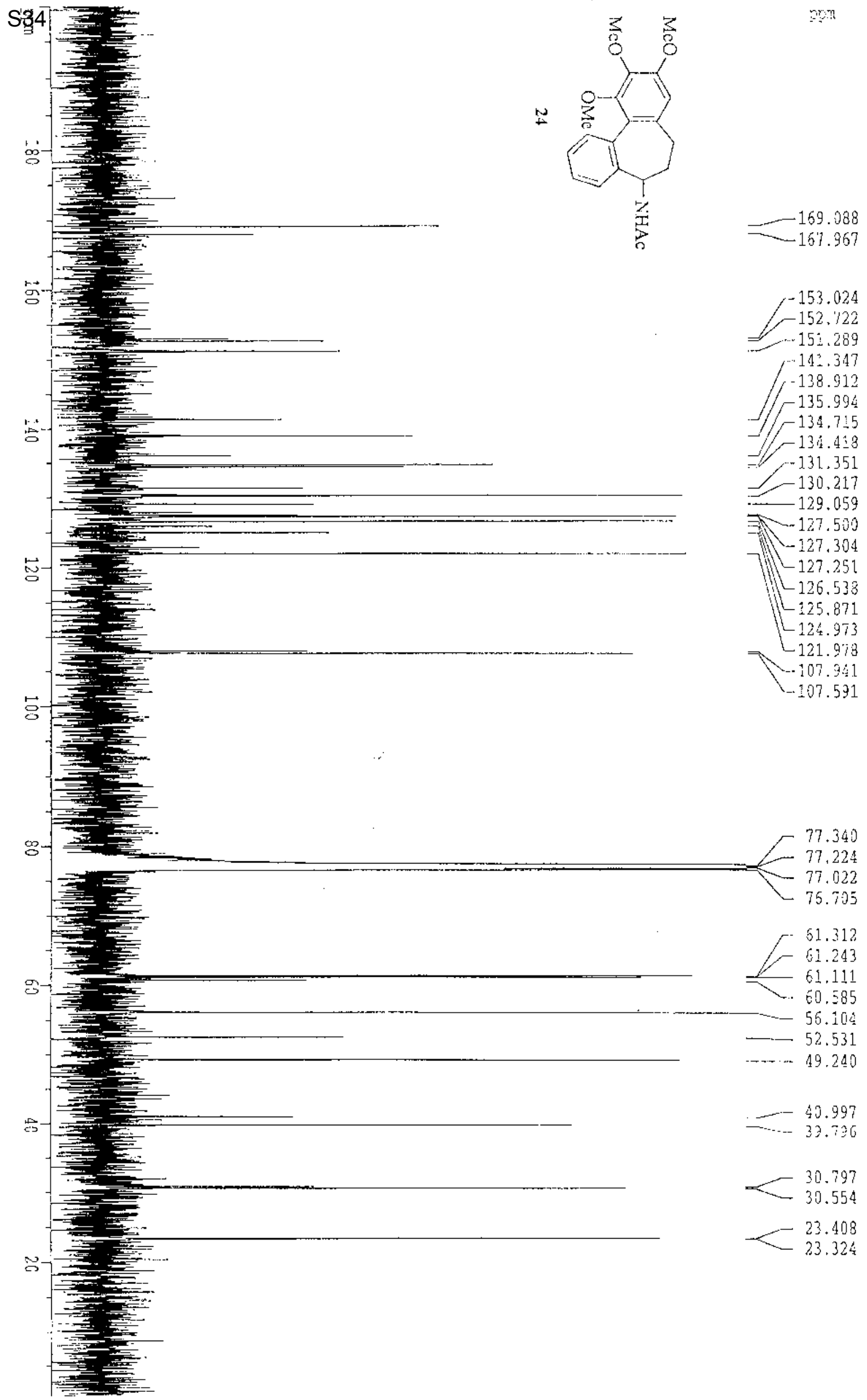



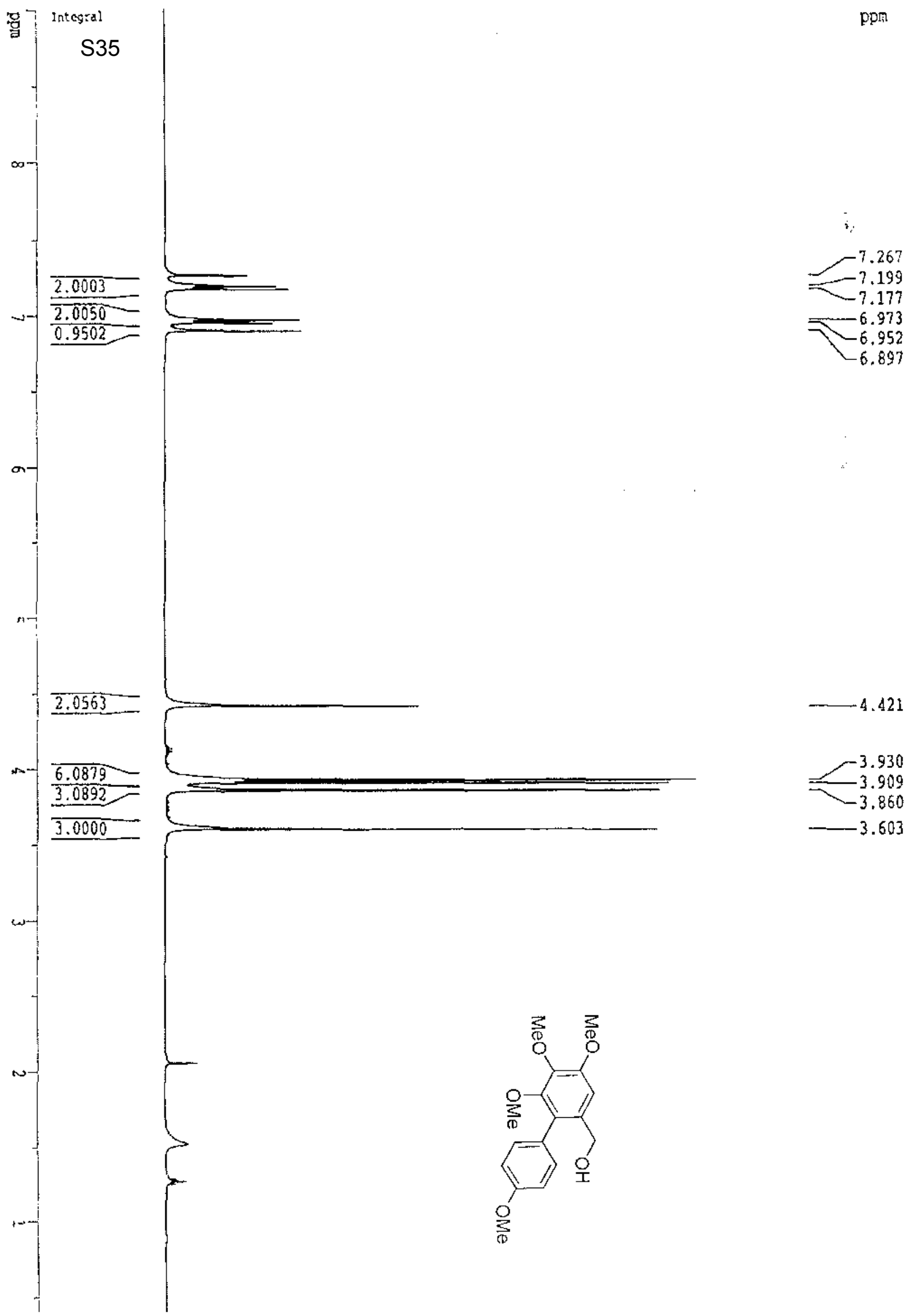
S36

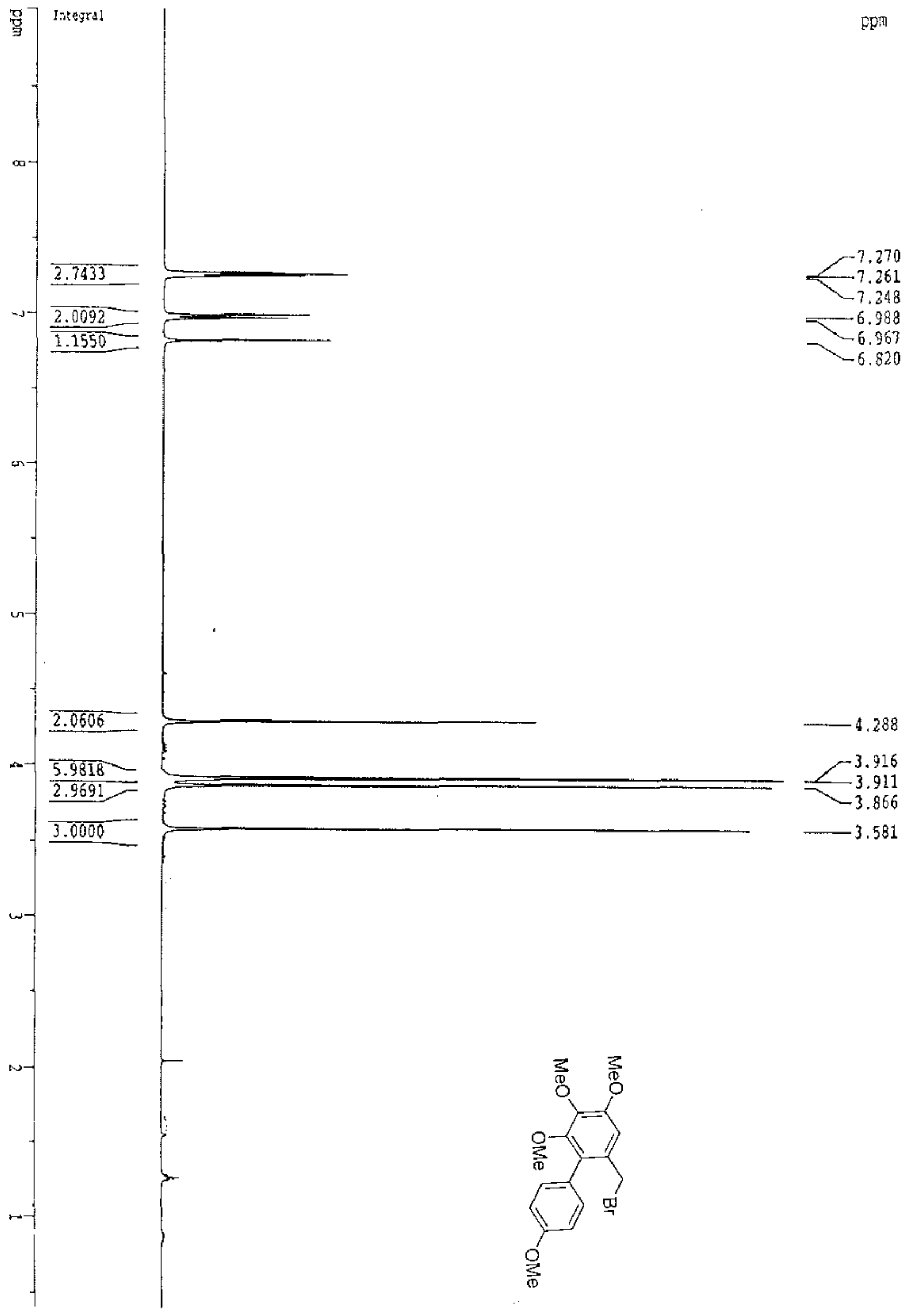




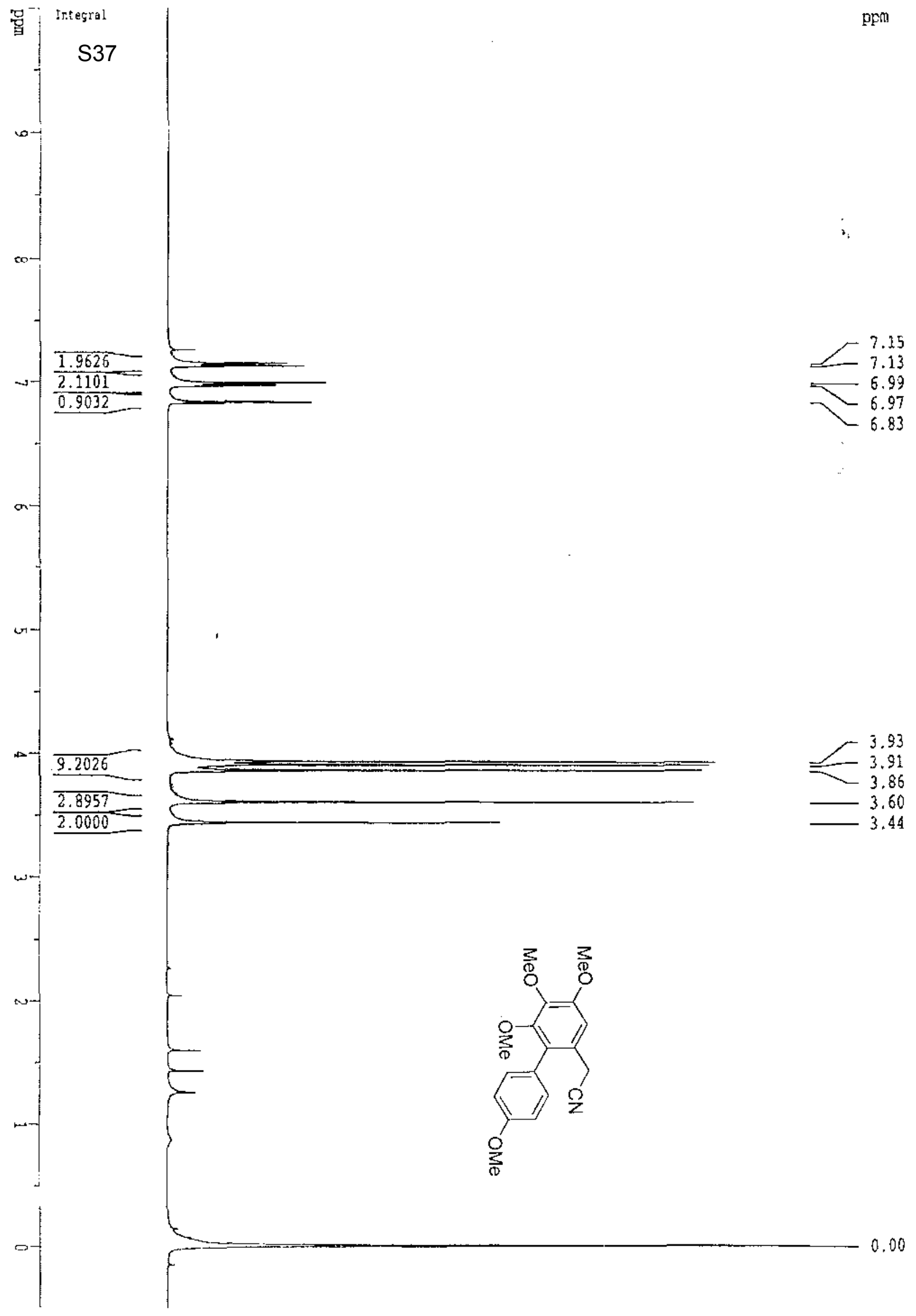




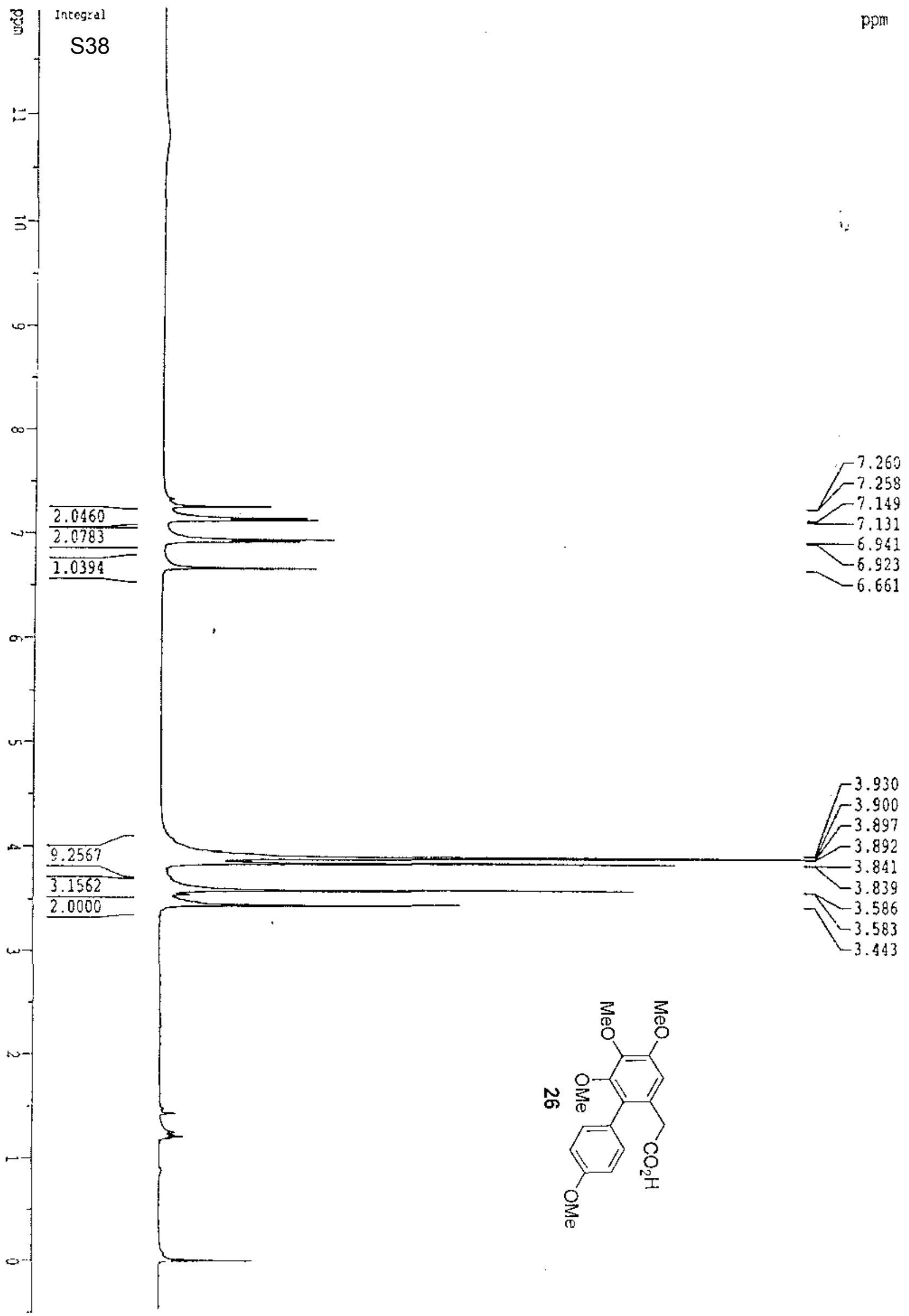




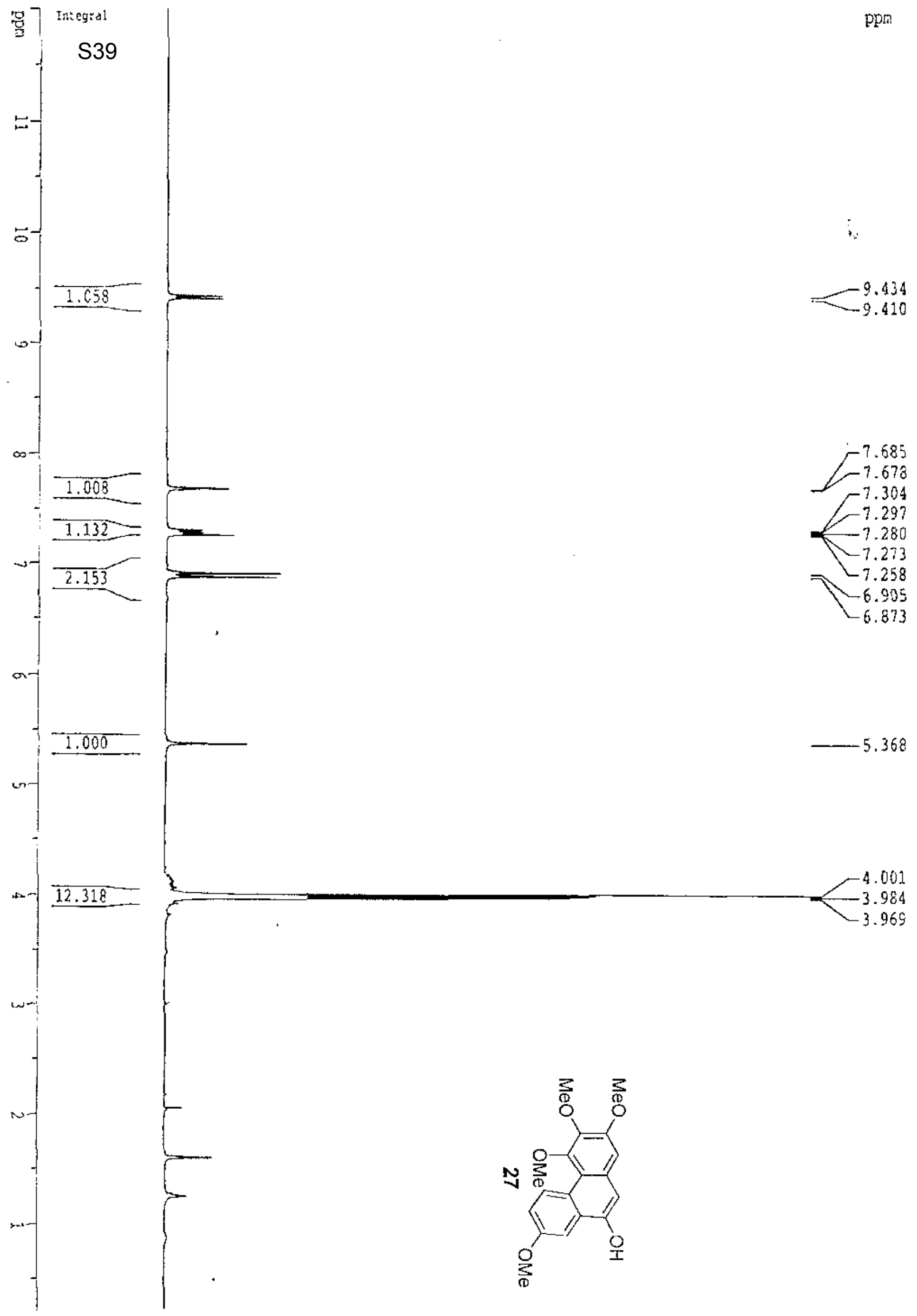




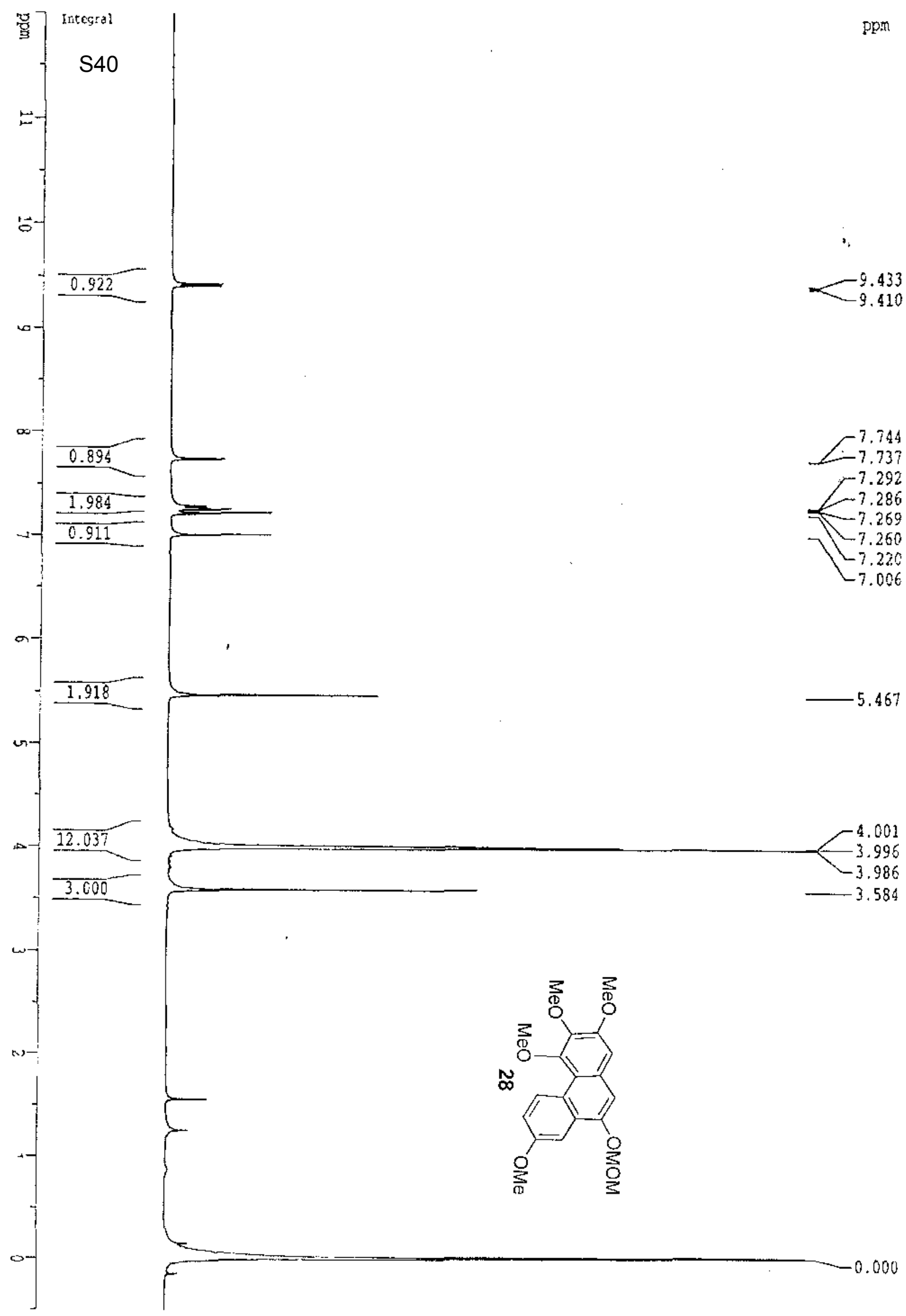




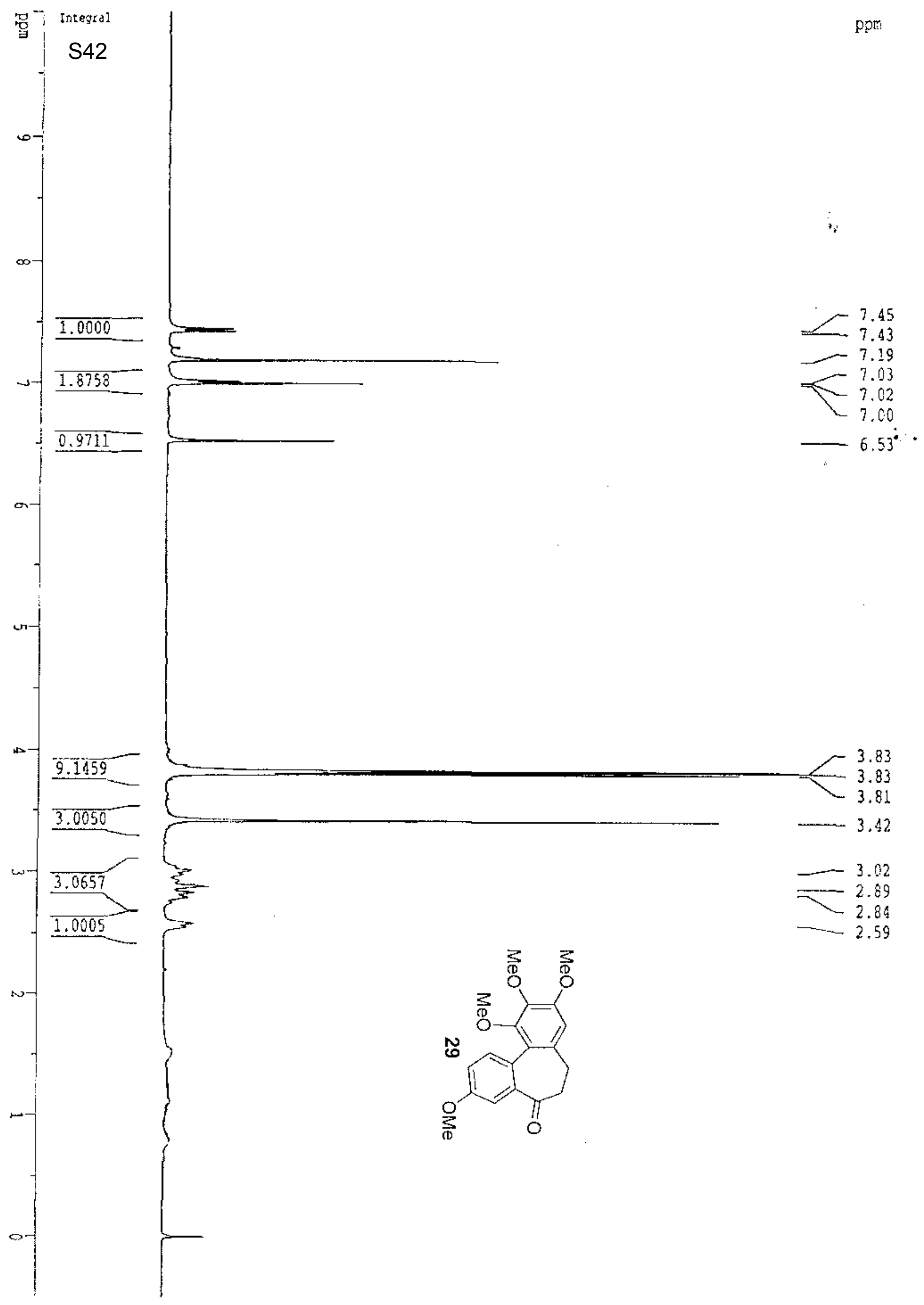




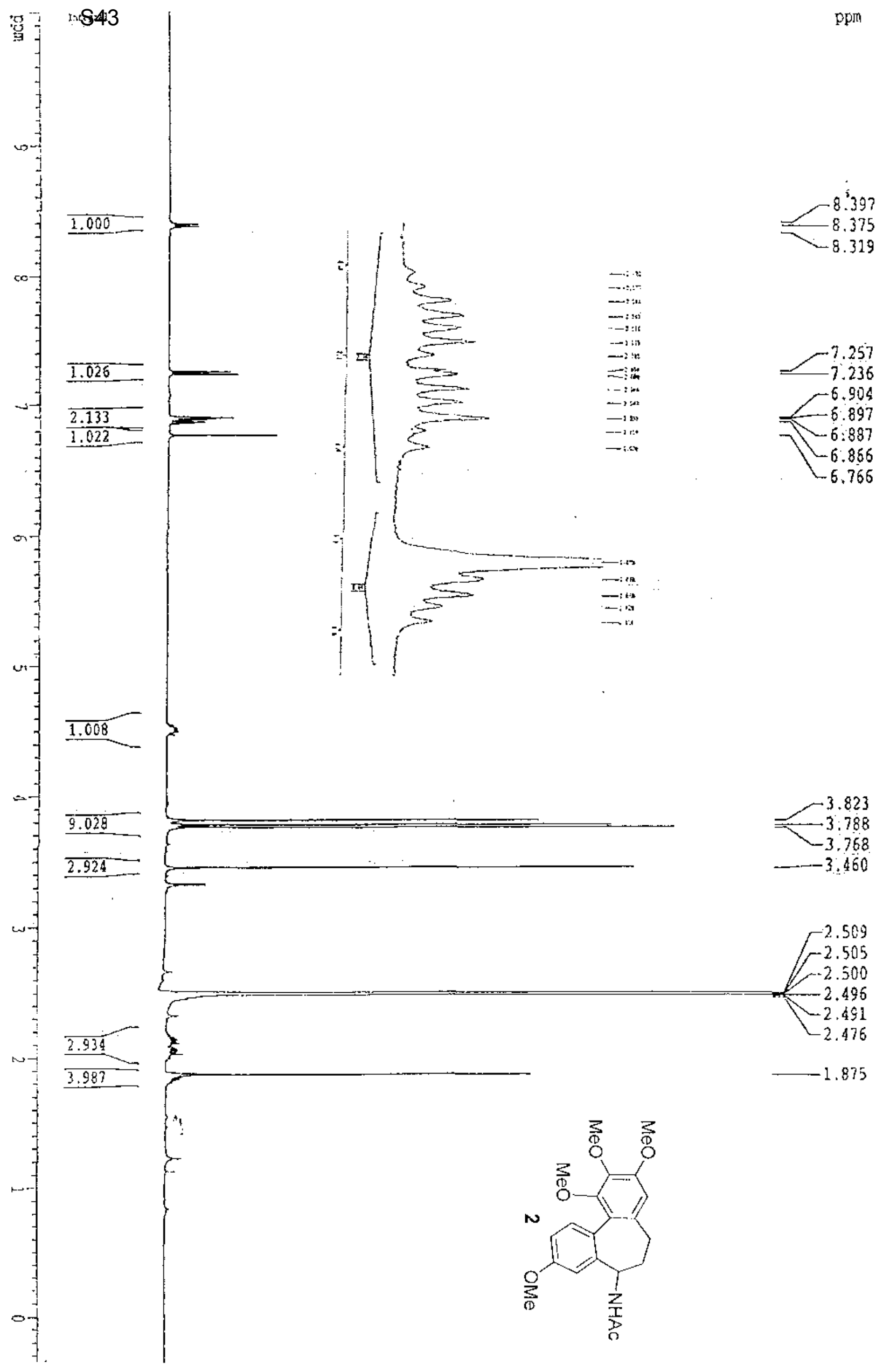




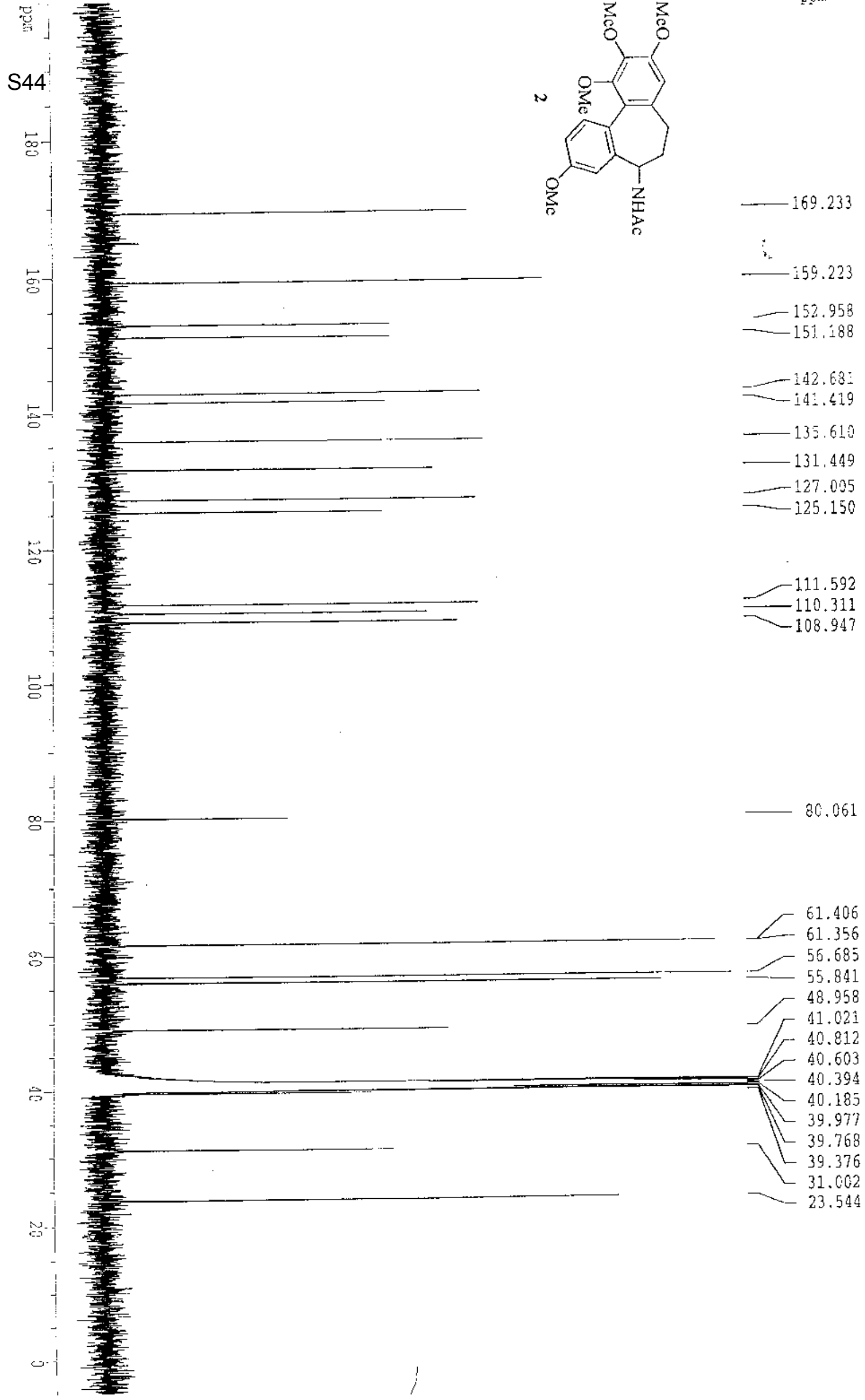

